This report was prepared as an account of work sponsored by an agency of the United States Government. Neither the United States Government nor any agency thereof, nor any of their employees, makes any warranty, express or implied, or assumes any legal liability or responsibility for the accuracy, completeness, or usefulness of any information, apparatus, product, or process disclosed, or represents that its use would not infringe privately owned rights. Reference herein to any specific commercial product, process, or service by trade name, trademark, manufacturer, or otherwise does not necessarily constitute or imply its endorsement, recommendation, or favoring by the United States Government or any agency thereof. The views and opinions of authors expressed herein do not necessarily state or reflect those of the United States Government or any agency thereof.

\title{
Literature Review of Arc/Plasma, Combustion, and Joule-Heated Melter Vitrification Systems
}

\author{
C. J. Freeman \\ G. P. Abrigo \\ P. J. Shafer \\ R. A. Merrill
}

July 1995

Prepared for

the U.S. Department of Energy

under Contract DE-AC06-76RLO 1830

Pacific Northwest Laboratory

Richland, Washington 99352 


\section{DISCLAIMER}

Portions of this document may be illegible in electronic image products. Images are produced from the best available original document. 


\section{SUMMARY}

This report provides reviews of papers and reports for three basic categories of melters: arc/plasma-heated melters, combustion-heated melters, and joule-heated melters. The literature reviewed here represents those publications which may lend insight to phase I testing of low-level waste vitrification being performed at the Hanford Site in FY 1995. For each melter category, information from those papers and reports containing enough information to determine steady-state mass balance data is tabulated at the end of each section. The tables show the composition of the feed processed, the off-gas measured via decontamination factors, gross energy consumptions, and processing rates, among other data. 



\section{CONTENTS}

SUMMARY

iii

ACRONYMS AND ABBREVIATIONS vii

1.0 INTRODUCTION.

1.1 ORGANIZATION.

1.2 FURTHER INFORMATION.

$2.0 \quad$ ARC/PLASMA-HEATED MELTERS

2.1 ANNOTATED BIBLIOGRAPHIES OF VITRIFICATION LITERATURE.

2.1

3.0 COMBUSTION-HEATED MELTERS

3.1 ANNOTATED BIBLIOGRAPHIES OF VITRIFICATION LITERATURE

3.1

4.0 JOULE-HEATED MELTERS

4.1

4.1 ANNOTATED BIBLIOGRAPHIES OF VITRIFICATION LITERATURE

4.1

\section{TABLES}

2.1. OPERATIONAL AND PEFORMANCE DATA FOR ARC/PLASMA-HEATED MELTERS.

3.1 OPERATIONAL AND PEFORMANCE DATA FOR COMBUSTION-HEATED MELTERS

4.1 OPERATIONAL AND PEFORMANCE DATA FOR JOULE-HEATED MELTERS 4.19 



\section{ACRONYMS AND ABBREVIATIONS}

«

ac

ACFM

Alfrax-66

B\&W

BWID

CFM

CMS

CPF

dc

DF

DSSF

DWPF

EPA.

EPI

ESCM

ETP

EVS

FRG

HEME

HLLW

HLW

HWVP

IDMS

INEL

$\mathrm{K}-3$

$\mathrm{kg}$

$\mathrm{kW}$

LFCM

LLW

LSFM

MSW

MTF

NCAW

PCT

PEC

PNL

PSCM

RLFCM

SAIC

SCFM

SCM

SGM

SITE

SRL

inches

fFeet

alternating current

actual cubic feet per minute

Carborundum castable refractory

Babcock and Wilcox

Buried Waste Integrated Demonstration

calcine-red melter

combustion melting system (Vortec)

Chemical Processing Facility

direct current

decontamination factor (off-gas mass/feed mass)

double-shell slurry feed (Hanford)

Defense Waste Processing Facility

Environmental Protection Agency

Electro-Pyrolysis, Incorporated

experimental-scale ceramic melter (PNL)

Emerging Technologies Program

ejector venturi scrubber

Federal Republic of Germany

high efficiency mist eliminator

high-level liquid waste

high-level waste

Hanford Waste Vitrification Plant

Integrated DWPF Melter System

Idaho National Engineering Laboratory

Carborundum Monofrax series fuse-cast refractory

kilogram

kilowatt

liquid-fed ceramic melter (PNL)

low-level waste

large slurry-fed melter (SRL)

municipal solid waste

Mock-up Test Facility

neutralized current acid waste (Hanford)

product consistency test

-Plasma Energy Corporation

Pacific Northwest Laboratory

pilot-scale ceramic melter (PNL)

radioactive liquid-fed ceramic melter (PNL)

Science Applications International Corporation

standard cubic feet per minute

small cylindrical melter (SRL)

scale glass melter

Superfund Innovative Technology Evaluation

Savannah River Laboratory 
SS

SSHTM

st

TCLP

TVF

USBM

WEC

WHC

WSTC

WVSP stainless steel

small-scale high temperature melter (PNL)

short ton

toxicity characteristic leach procedure

Tokai Vitrification Facility

U.S. Bureau of Mines

Westinghouse Electric Corporation

Westinghouse Hanford Company

Westinghouse Science and Technology Center

West-Valley Support Project 


\section{$1.0 \quad$ INTRODUCTION}

This document compiles literature reviews of a number of vitrification test reports generated by government contractors and commercial industries. The reviews were prepared by the Pacific Northwest Laboratory's (PNL) ${ }^{\text {(a) }}$ Vitrification Technology Development (PVTD) Project in support of the FY-95 Hanford low-level waste (LLW) vitrification vendor testing. The focus of this review was to include, at a minimum, literature information that may be relevant to the first phase of that effort. During phase 1, seven vendors generated and provided LLW vitrification data for the program. Each vendor used one of these three basic vitrification systems:

(1) Arc/Plasma-Heated Melters

(2) Combustion-Heated Melters

(3) Joule-Heated Melters

Although the phase-1 testing data covers important operational and performance information, other important data could not be obtained from these tests because of testing circumstances and durations. Such data include long-term corrosion information, volatility/off-gas information for varying compositions, phase separation data for instances of reduced metals or accumulated salts, operational data that may lead to improvements or explanations of testing performance, and design aspects that may provide alternatives or enhancements for the given system. This document provides information on those topics from the available literature.

Although much literature exists on vitrification testing with the systems of interest, many test reports were not included in the present literature review. For example, some reports were not included because they described bench-scale or smaller forms of testing only. Since the LLW phase-1 test effort deals with pilot-scale systems, the background literature was screened to summarize similarly sized systems. In addition, test reports that did not contain reasonable levels of data were not included in this literature review.

\subsection{ORGANIZATION}

Within each vitrification system category, the individual literature references are cited, followed by a brief annotation of the reference's contents. Those references containing enough information to show steady-state mass balance data are further described in a table at the end of each section. For each applicable reference, the tables show the composition of the feed processed, the off-gas measured via DFs (decontamination factors), gross energy consumptions, processing rates, etc. It is important to note that not all of the key information could be incorporated into the tables. To provide further guidance for the reader, much of the information that could not be incorporated in the tables is underlined in the annotated bibliographies and marked with margin notes. These margin notes correspond to related information mentioned previously and read, "Off-gas," "Composition," "Operation," "Corrosion," "Phase sep." (for phase separation), and "Design."

(a) The Pacific Northwest Laboratory is operated by Battelle Memorial Institute for the U.S. Department of Energy under Contract DE-AC06-76RLO 1830. 


\subsection{FURTHER INFORMATION}

Some of the reviews provided in the following sections are from references that were prepared as internal publications, and as such may not be listed in the archival systems provided by libraries, journals, or federal agencies. To receive copies of those references or to obtain ordering information, please contact PNL's Vitrification Technology Development Project at this address:

Vitrification Technology Development Project

Pacific Northwest Laboratory

Battelle Blvd.

P.O. Box 999 , K9-80

Richland, WA 99352 


\subsection{ANNOTATED BIBLIOGRAPHIES OF VITRIFICATION LITERATURE}

1. Elger, G.W., et al. 1987. RI 9130: "Utilization of scrap preheating and substitute slag conditioners for electric arc furnace steelmaking." U.S. Bureau of Mines. Albany, OR.

The effect of preheating metal scrap feed, using the furnace off-gas, on specific power consumption was investigated. Cold and preheated scrap were fed into the U.S. Bureau of Mines melter at rates between 37.5 and $43.7 \mathrm{lb} / \mathrm{min}$, respectively. Overall energy consumptions were $888 \mathrm{~kW} \mathrm{~h} / \mathrm{st}$ for cold scrap, $829 \mathrm{~kW} \mathrm{h/st} \mathrm{for}$ preheated scrap, and $637 \mathrm{~kW} \mathrm{h/st} \mathrm{for} \mathrm{conventional} \mathrm{backcharged} \mathrm{scrap.} \mathrm{Graphite}$ electrode consumption during the tests ranged from 13 to $16 \mathrm{lb} / \mathrm{st}$ of scrap processed.

2. Brent, Allon Dudley. July, 1987. Mintek Report No. M304: "The Smelting of Ilmenite in a dc Transferred-Arc Plasma Furnace with a Molten-Anode Configuration." Council for Mineral Technology. Randburg, South Africa.

Ilmenite ore was reduced to a titanium slag using a 50-kW Mintek Transferred-Arc Plasma Furnace in South Africa. The titanium slag was to be used as feedstock for titanium tetrachloride. A graphite cathode and soft iron anode were used to generate a transferred arc through the material. Ten liters per minute of argon was used to stabilize the arc. Calcined anthracite was used as the reducing agent in these tests. The titanium slag produced during the tests met the minimum titanium dioxide grade required for chlorinator feed stocks. However, the maximum magnesia oxide specifications were exceeded as the magnesia in the crucible walls dissolved into the slag.

3. Peters, R.D. and Ross, W.A. October, 1987. PNL-SA-15432: "Plasma Melting of Non-Irradiated Fuel Assembly Hardware: Initial Testing and Evaluation." Pacific Northwest Laboratory, Richland, WA.

A pressurized water reactor (PWR) fuel assembly cage (composed of 49 wt\% 304 SS, $26 \mathrm{wt} \%$ Inconel 718 , and $25 \mathrm{wt} \%$ zircaloy) was melted in a $250-\mathrm{kW}$ plasma torch furnace designed by Retech, Inc. of Ukiah, CA. A main torch rated at $250 \mathrm{~kW}$ and an auxiliary torch rated at $75 \mathrm{~kW}$ were both used during the test and operated in transferred arc mode. After being processed by a plasma torch operating at temperatures greater than $3000^{\circ} \mathrm{C}$ the $8.5^{\prime \prime} \times 8.5^{\prime \prime} \times 14^{\prime}$ long cage melted into a dense metal ingot giving an overall volume reduction factor of 42 . The melting rates during the tests ranged from 0.6 to $1.4 \mathrm{~kg} / \mathrm{min}$, with an average melting rate of $50 \mathrm{~kg} / \mathrm{hr}$. The torch powers ranged between 2.4 and $6.4 \mathrm{~kW} \mathrm{~h} / \mathrm{kg}$. The melt test lasted 37.8 minutes. Argon gas was used to create an inert atmosphere in the furnace. No volatility or corrosion data were given. 
4. Falk, D.E., Lahoda, E.J. and Mitchell, J.L. September, 1988. "Nitrate Destruction by A Plasma Torch." Westinghouse Electric Corporation Environmental Services Division. Madison, PA.

A proof-of-principle experiment was conducted to demonstrate that metal nitrates could be converted to solid oxides using a plasma torch. A blown-arc Marc 3 plasma torch with a $75-\mathrm{kW}$ to $120-\mathrm{kW}$ power rating was used. Air was blown through the two electrodes at a high rate, typically between 10 and 25 SCFM. A liquid slurry containing metal nitrates, nitric acid and water was injected into a plasma furnace. Some feeding problems were encountered, so the feed nozzle and feed dilution were modified. The average temperature at the exit of the plasma chamber was $1062^{\circ} \mathrm{C}$. The calculated average axial temperature was $1558^{\circ} \mathrm{C}$. A mass balance was performed on the system and the total amount of solids carryover was estimated.

5. U.S. Environmental Protection Agency. October, 1988. "Update of Innovative Thermal Technologies." Cincinnati, $\mathrm{OH}$.

Five thermal technologies were described for the treatment of various waste streams. Plasma arc technology was generally described along with several case studies. Tests were described in which a mobile plasma arc unit was used to treat carbon tetrachloride and PCBs. The plasma unit achieved a greater than $99.99 \%$ destruction efficiency for both of these organics.

6. Aerospatiale. 1991. "Plasma on a Foundry Cupola." Aerospatiale. Paris, France.

Industrial-scale demonstration tests on the use of a de plasma torch in a production foundry cupola were performed in France during 1986 and 1987. This facility was used for reprocessing scrap metal at a rate of 85,000 tons per year. No information was given on product quality or carryover of solids into the off-gas. The plasma torch was used only to increase the blast air from ambient to $400^{\circ} \mathrm{C}$. The addition of a plasma torch enhanced the performance of the process. The plasma torches used in the tests had accumulated 2.500 working hours. The water-cooled electrodes were copper or copper-alloy. The air used as a plasma gas was injected into the torch to produce a vortex. This air flow was typically less than $1000 \mathrm{~m}^{3} / \mathrm{hr}$ at $2 \mathrm{MW}$ power. The operating lifetime of the electrodes was greater than 500 hours for the cathode and greater than 700 hours for the anode. The average torch efficiency was $82 \%$.

7. Detering, B.A. and Batdorf, J.A. 1992. "Plasma Treatment of INEL Soil Contaminated with Heavy Metals." Idaho Falls, ID.

INEL soil was spiked with inorganic salts of chromium, lead, mercury, silver and zinc and vitrified into a glassy slag product using a $150-\mathrm{kW}$ Plasma Energy Corporation (PEC) Plasma Tilt Furnace. No plasma torch specifications were given. Ten tests were conducted over 11.2 hours. The first five tests processed INEL soil without any added flux and the last five tests treated INEL soil with sodium carbonate flux added. The glassy slag produced by these tests retained very little of 
the spiked metals. EPA toxicity characteristic leachate procedure (TCLP) analyses were performed on random product samples. Due to the low metal concentrations in the glassy slag product, all the product slags passed EPA limits for metals leached. No information on carryover of solids into the off-gas was reported but it was assumed that a significant amount of the metal salts volatilized. The authors attributed this volatilization to: 1) using a loose powdery soil as a feed material, which allowed volatile metals to vaporize before being incorporated into the melt; 2) using metal nitrate salts which had low melting points $\left(<500^{\circ} \mathrm{C}\right)$; and 3) passing the feed directly through the hot plasma flame (temperatures between $10,000 \mathrm{~K}$ and $20,000 \mathrm{~K}$ ). Some refractory erosion was qualitatively described.

8. Zaghloul, H.H., and Circeo, L.J. 1993. "Destruction and Vitrification of Asbestos Using Plasma Arc Technology." U.S. Army Construction Engineering Research Laboratories. Champaign, IL.

This report describes an asbestos vitrification experiment using a PT-150 plasma arc tilt-furnace at the Test and Demonstration Facility (TDF) of the Plasma Energy Corporation. The 16 " diameter furnace was equipped with a $300-\mathrm{kW}$ plasma torch. Torch specifications such as transferred arc or non-transferred arc operation, dc or ac power, and plasma gas used were not reported. Approximately 25 pounds of chrysotile asbestos in metal containers were fed into the furnace over a 35 minute period. The torch operated at around $170 \mathrm{~kW}$ and the glass temperature was approximately $1300^{\circ} \mathrm{C}$. Samples were taken of the vitrified product (asbestos and metal canister residue), furnace residue, and air both inside and outside the off-gas pipe. Analysis of the samples indicated trace amounts of asbestos in the residues and off-gas.

9. Hartman, A., Oden, L., and White, J. 1993. RI9476: "Facility for Melting Residues From Municipal Waste Combustion: Design Criteria and Description of Equipment." U.S. Bureau of Mines. Albany, OR.

This report describes a three-phase electric arc melting furnace system built by the U.S. Bureau of Mines. The design consists of a mechanical feed-handling system, electric arc melting furnace, fume-offgas handling system, and thermal oxidizer for final offgas treatment. Screw conveyors and a bucket elevator can deliver up to $2000 \mathrm{lb} / \mathrm{hr}$ of material to the furnace. The inside diameter of the furnace is approximately 4 feet. The furnace uses three 4" diameter graphite electrodes. Slag is tapped continuously from the water-cooled copper tap-hole into $1000 \mathrm{lb}$ capacity conical cast iron molds.

10. Surma, J.E., et al. June, 1993. PNL-8525: "Evaluation of the Graphite Electrode dc Arc Furnace for the Treatment of INEL Buried Wastes." Pacific Northwest Laboratory. Richland, WA.

Thirteen 2-hour-long demonstration tests were performed in a graphite electrode dc arc furnace using Idaho National Engineering Laboratory simulated buried wastes. These tests included melting soils with added metals, sludges, combustibles, and simulated drums. The tests were performed at the MIT Plasma Fusion Center using an Electro-Pyrolysis, Inc. (EPI) Mark-I plasma furnace. The graphite electrodes did 
not require any cooling. The 21 " high graphite crucible, in which the waste was melted, was 12.5 " in diameter at the bottom and $13.5 "$ in diameter at the top. Nitrogen was injected into the plasma furnace at a rate of approximately 5 SCFM to reduce attack on the graphite. The plasma furnace was operated in transferred-arc mode with the arc being maintained between the cathode and the molten material. The energy required averaged $1.5 \mathrm{~kW} \mathrm{~h} / \mathrm{kg}$ of glass and the estimated glass temperatures in the melt were between 1400 and $1600^{\circ} \mathrm{C}$. The glasses produced during these tests were highly reduced, but it was unclear if this had any effect on the product quality as no durability results were reported. Some particulate buildup in the off-gas pipe was observed. Retention of $\mathrm{Cs}$ in the glass product was measured to be between 98.1 and $99.1 \mathrm{wt} \%$. The 2" diameter graphite cathode was consumed at a rate of approximately 1.2 pounds per test. Erosion of the graphite pot anode (positive electrode) was reported to be significantly higher than the cathode but was not quantified.

11. O’Connor, W. O., Oden, L., Turner, P., and Davis D. October, 1993. ALRC 93-62: "U.S. Bureau of Mines small-scale arc melter tests on simulated low-level radioactive wastes." U.S. Bureau of Mines. Albany, OR.

The U.S. Bureau of Mines conducted 30 hours of vitrification testing on simulated low-level radioactive wastes from the INEL Radioactive Waste Management Complex (RWMC). The RWMC soil and five waste compositions were melted in a 50-lb capacity, single-phase electric arc furnace. The material balance for the furnace operation indicated that between 63 to $84 \%$ of the feed went to the slag. Slag temperatures as low as $1250^{\circ} \mathrm{C}$ were required to melt the $\mathrm{RWMC}$ soil, but temperatures in excess of $1600^{\circ} \mathrm{C}$ were necessary for the slag to pour. Fifteen tests were performed with batch temperatures ranging from $1250^{\circ} \mathrm{C}$ to $1800^{\circ} \mathrm{C}$ and power requirements ranging from $0.85 \mathrm{~kW} \mathrm{h/lb}$ to $1.6 \mathrm{~W} \mathrm{~h} / \mathrm{lb}$. Overall material balances were given. Particulate DFs, calculated from feed and baghouse masses, ranged from 27 to 60 for the tests. No corrosion information was given.

12. O'Connor, W. O., Oden, L., and Turner, P. December, 1993. ALRC 92-58: "Vitrification of Municipal Waste Combustor Residues: Physical and Chemical Properties of Electric Arc Furnace Feed and Products." U.S. Bureau of Mines. Albany, OR.

Vitrification tests of five different incinerator residues in the U.S. Bureau of Mines arc melter were conducted over 200 hours. Four of the incinerator residues produced noncrystalline glass materials while another residue product was predominantly crystalline. All of the solidified products passed TCLP tests. Fume solids collected exceeded limits for $\mathrm{Pb}$ and/or $\mathrm{Cd}$. Overall decontamination factors ranged from 5.6 to 12 during the tests. No corrosion information was given.

13. Oden, L., O'Connor, W. O., Turner, P., and Hartman, A. January 1994. ALRC 94-08: "Evaluation of Three-Phase Electric Arc Melting Furnace for Treatment of Simulated, Thermally Oxidized Radioactive and Mixed Wastes: Part 1. Design Criteria and Description of Integrated Waste Treatment Facility." U.S. Bureau of Mines. Albany, OR. 
A detailed description of the U.S. Bureau of Mines arc-furnace system is given. The melter is a 1 metric ton capacity, three-phase, $800-\mathrm{kW}$ electric arc melting furnace with 4" diameter graphite electrodes. The roof and sidewalls of the furnace, the four feed tubes, the section of air pollution control duct that penetrates the furnace roof, and the copper fixture for continuous tapping of slag are water cooled. The feed system is composed of a $60-\mathrm{ft}^{3}$ receiving bin equipped with twin, counter-rotating screws in the base of the bin which discharge material to a bucket elevator. The feed is transferred to a metering bin equipped with delivery screws and then discharged into the melter through four ports in the furnace roof. The furnace is tapped and drained through a 1-1/2" diameter hole in the bottom center of the hearth. The copper slag-tapping fixture is water cooled and designed to permit continuous tapping of slags at rates up to $2.200 \mathrm{lb} / \mathrm{hr}$. The air pollution control system (APCS) is composed of fume traps, heat exchangers, a baghouse, a HEPA filter, and a 10-hp induced draft fan. Gortex-membrane Teflon-coated fiberglass bags rated to remove $99.98 \%$ of particulates greater than $3 \mathrm{~mm}$ at flowrates up to 2,000 ACFM were used. No corrosion or experimental data was presented.

14. McLaughlin, D.F., et al. April, 1994. STC Report 93-9TDO-CALCN-R2: "Plasma Calcination of Simulated High-Level Nuclear Waste (Test CDT-2) - Final Report." Westinghouse Science and Technology Center (WSTC). Pittsburgh, PA.

Nearly $3900 \mathrm{~kg}$ of simulated high-level waste slurry was processed in a 10 -hour test to produce a total of $1780 \mathrm{~kg}$ of calcined product. The $1500 \mathrm{~kW}$ dc arc torch operated in blown-arc mode with the total average air flow through the system being 508 SCFM during the test. The average torch power was $1049 \mathrm{~kW}$. The plasma arc cupola had a 76-cm inner diameter and was approximately $6.7 \mathrm{~m}$ high. An organic destruction of $99 \%$ or greater was demonstrated during the test, along with between $\underline{86 \%}$ and $91 \%$ decomposition of nitrates and nitrites. Mass balances were also performed on the system. Based on the mass balance performed and visual observation, corrosion of the $\mathrm{Al}_{2} \mathrm{O}_{3}-\mathrm{Cr}_{2} \mathrm{O}_{3}$ ruby refractory seemed minimal but there was significant attack on the $\mathrm{Al}_{2} \mathrm{O}_{3}-\mathrm{SiO}_{2}$ refractory in the cupola shaft. Excess $\mathrm{PO}_{4}$ in the product glass also indicated corrosion of 90-RAM-PC refractory (a $\mathrm{P}_{2} \mathrm{O}_{5}$ containing refractory). Nickel coupons were suspended in the system and exposed to the calcination chemistry at 800 to $950^{\circ} \mathrm{C}$ for approximately 6 hours. Severe nickel corrosion was reported. Analysis of solid aerosols in the off-gas and scrubber efficiency calculations were also performed.

15. Soelberg, N.R. et al. July, 1994. EGG-WTD-11138: "Arc Melter Demonstration Baseline Test Results." U.S. Bureau of Mines. Idaho Falls, ID.

Pilot-scale electric arc melter tests were conducted on five mixtures of simulated buried wastes and soil. The test system included an automated feed system, an 800kVA ac power supply, a graphite electrode arc furnace designed for a steel capacity of 1 ton in the hearth, and an air pollution control system. Five mixtures of soil containing metals, $\mathrm{ZrO}_{2}, \mathrm{TiO}_{2}$ and evaporator nitrate salts were tested. All the waste mixtures contained 0.35 to $0.42 \%$ cerium oxide added as a surrogate for transuranic oxides. Tests were conducted in July 1993 and a total of over $55,000 \mathrm{lb}$ 
of material were melted and processed. Average feed and tap rates ranged from 600 to $1200 \mathrm{lb} / \mathrm{hr}$ with a maximum of $2,000 \mathrm{lb} / \mathrm{hr}$. Waste volume was reduced by a factor of 2.6. The five simulants were tested over five days with the actual operating time varying between 7.7 and 10.7 hours per day. The average energy use was $1.1 \mathrm{~kW} \mathrm{~h} / \mathrm{kg}$ of feed. Electrode consumption over the course of the tests was approximately $11.9 \mathrm{lb} /$ ton of feed or $12 \mathrm{lb} / \mathrm{MW} \mathrm{h}$. The furnace hearth composed of $\mathrm{MgO}$ was completely dissolved during the first test by the $\mathrm{S} 60$ slag but did not seriously affect operation. The sidewall, roof refractory and ruby brick underlying the hearth showed little wear. Mass balances were performed on the system for all the tests and particulate carryover into the off-gas line was calculated. Noncondensible off-gas was analyzed, including $\mathrm{CO}_{2}, \mathrm{H}_{2} \mathrm{O}, \mathrm{NO}_{\mathbf{x}}, \mathrm{SO}_{2}$, and $\mathrm{HCl}$.

16. Hendrickson, D.W. September 1994. WHC-SD-WM-TI-577, Rev. 1: "Preliminary Flow-sheet for Plasma Arc Calcination of Selected Hanford Site Tank Wastes." Westinghouse Hanford Company. Richland, WA.

Describes preliminary design and tests on the pretreatment of simulated high-level nuclear waste by plasma calcination. The purpose of plasma arc calcination was to destroy the organic compounds, ferrocyanide, and nitrite and nitrate in the waste. 
TABLE 2.1. OPERATIONAL AND PERFORMANCE DATA FOR ARC/PLASMAHEATED MELTERS

The following notations and abbreviations apply to the Table 2.1.

NA - Not Applicable

[ ] - Fraction Accumulated in Melter

NR - Not Reported

* - Calculated from Glass Analyses, Not Off-Gas

" " - Based on Target Values 

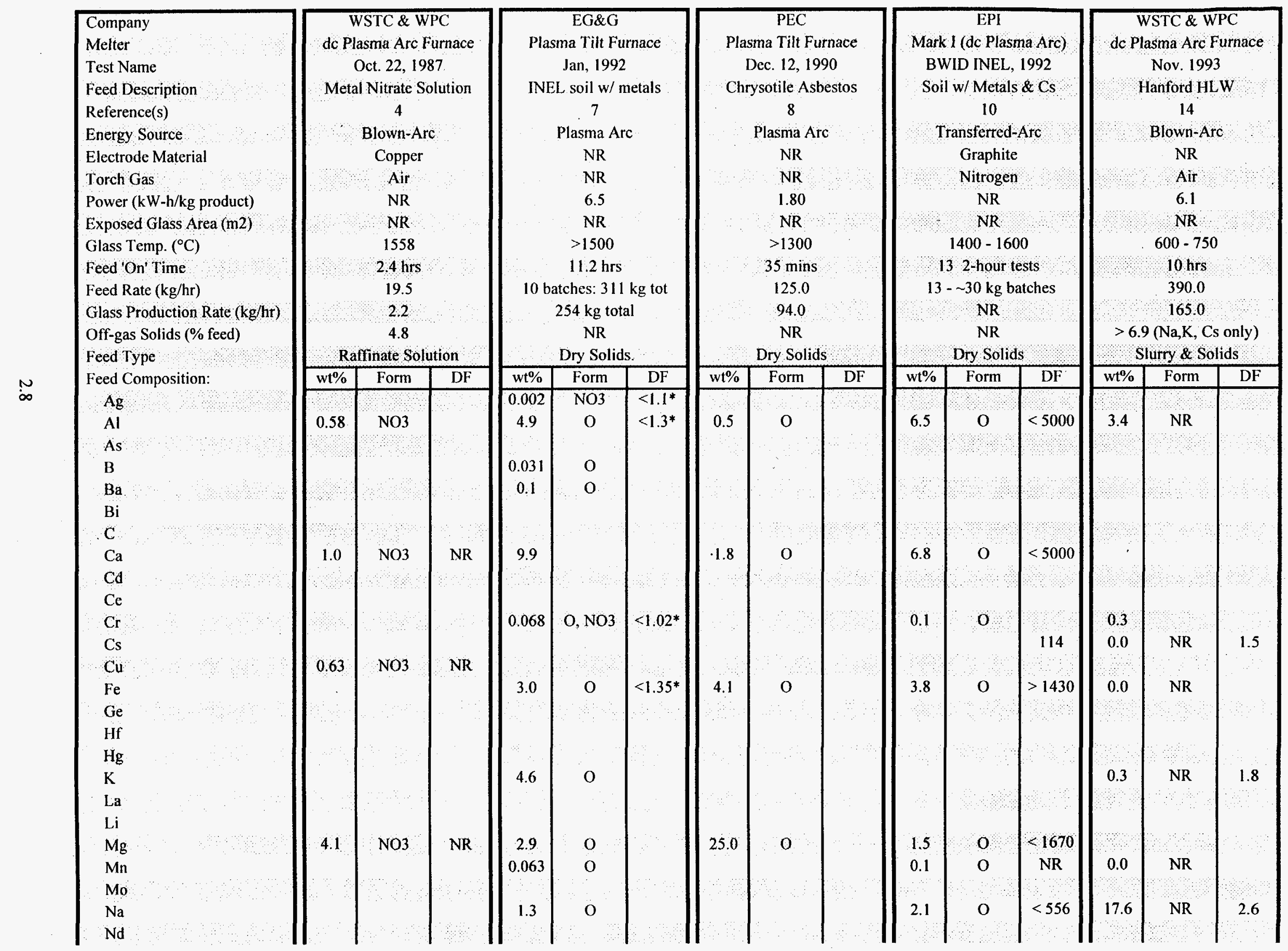


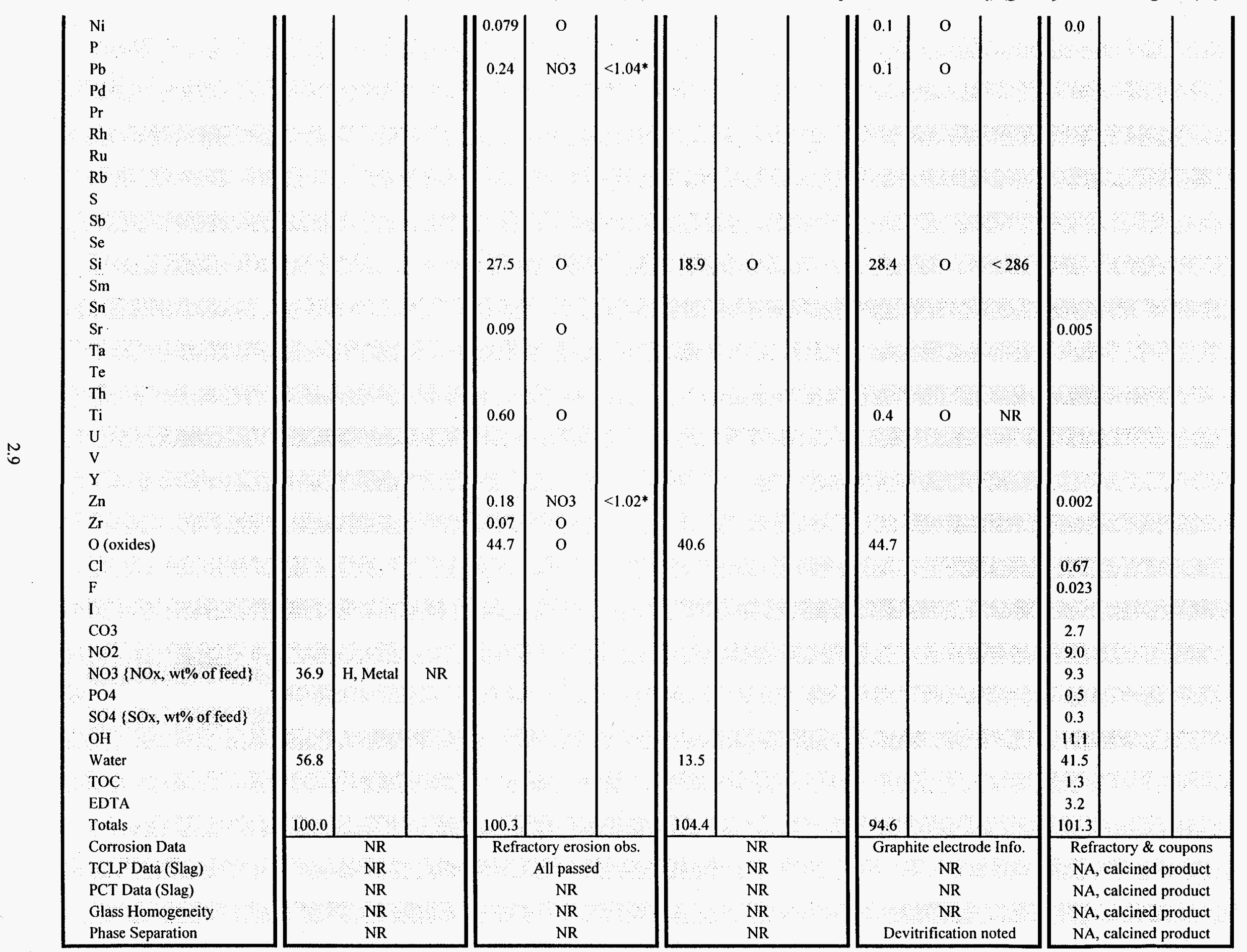



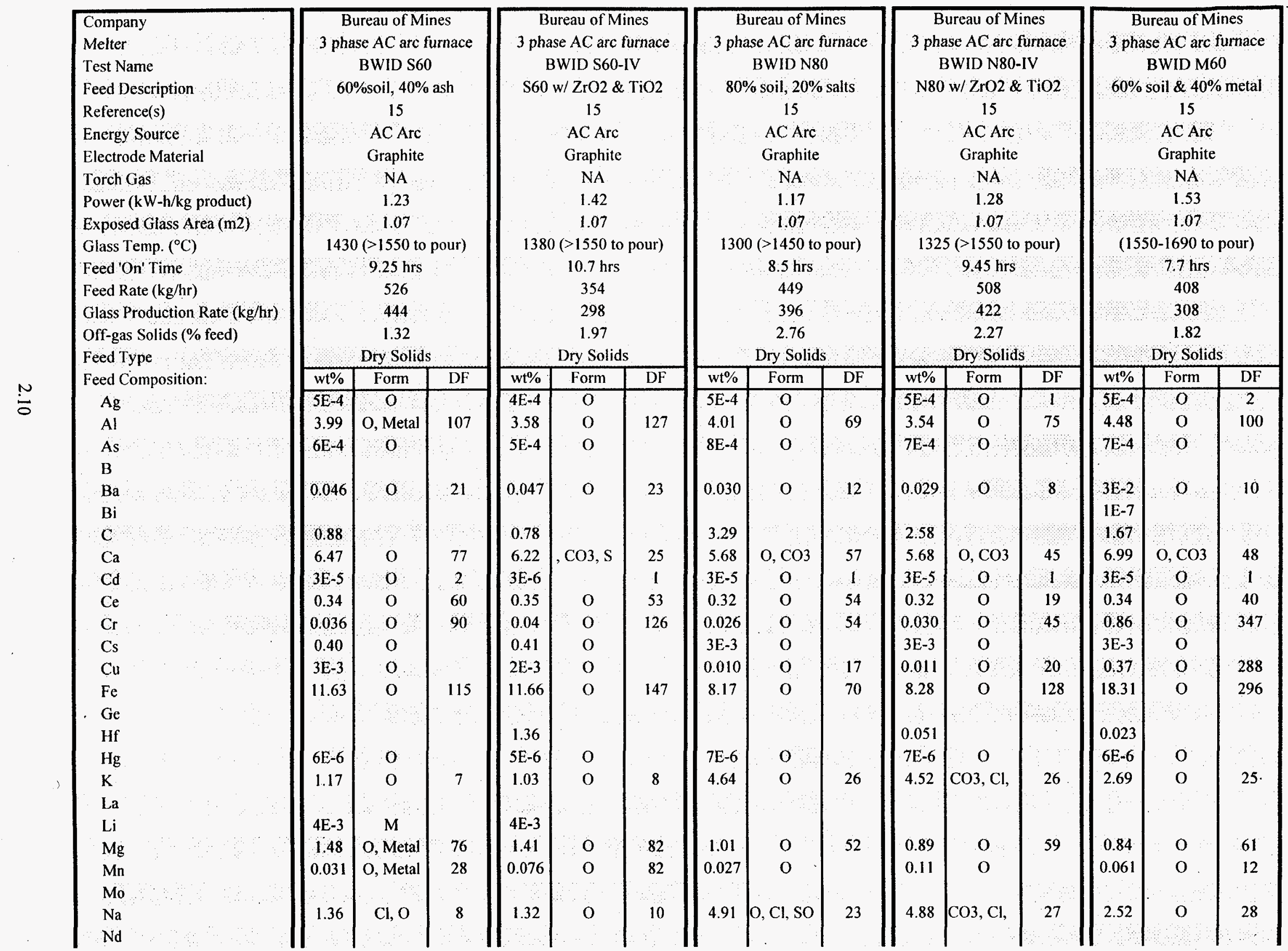


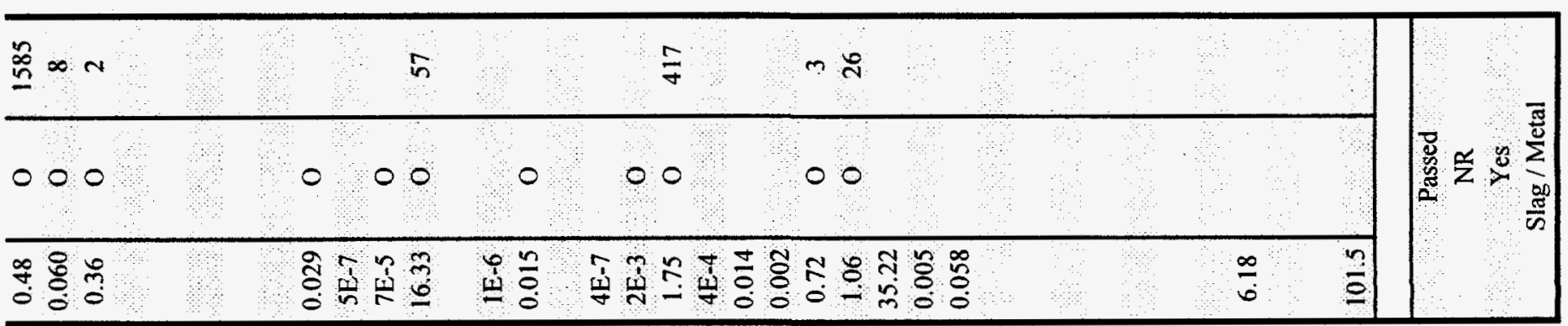

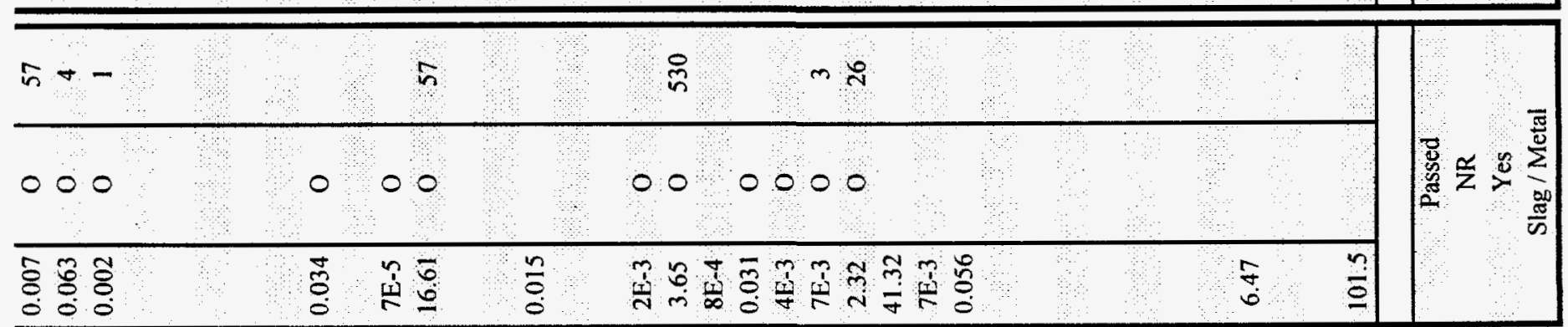

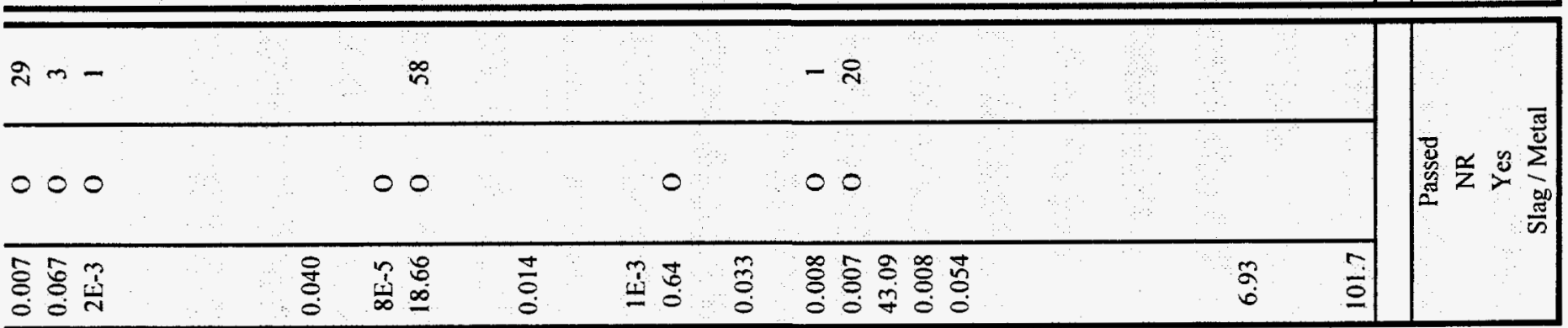

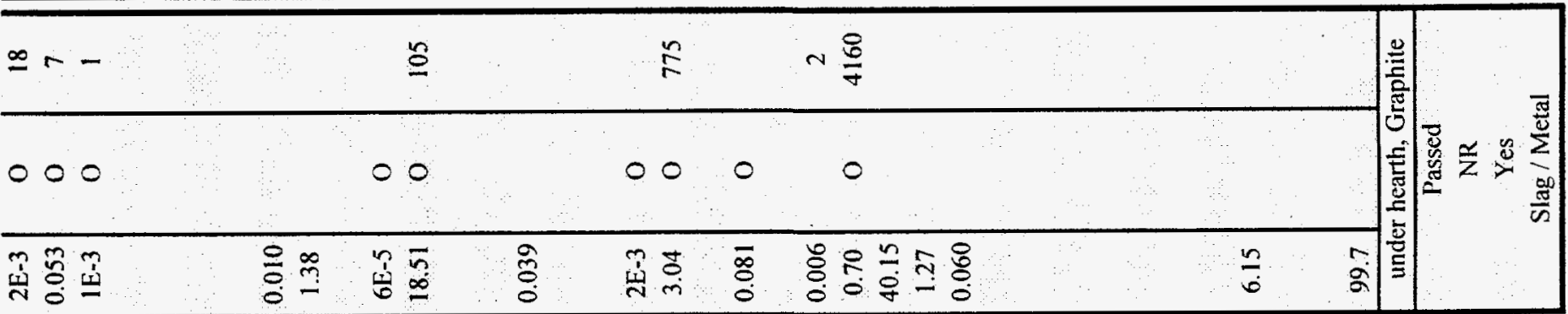

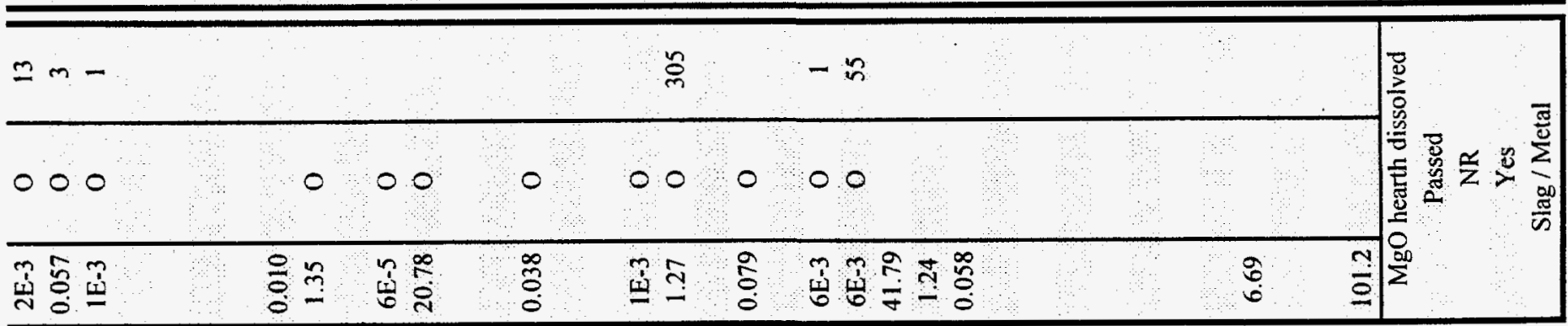




\subsection{ANNOTATED BIBLIOGRAPHIES OF VITRIFICATION LITERATURE}

1. Hnat, J.G. et al. (Vortec Corporation). 1990. "A Cyclone Melting System for Processing Hazardous Waste Dusts." Presented at the 1991 National Research \& Development Conference on the Control of Hazardous Materials.

Results of testing in Vortec's combustion melting system (CMS) from the vitrification of hazardous dusts (i.e., flyash, etc.) mixed with recycled waste glass. Approximately $4000 \mathrm{lb}$ of vitrified material was processed during the 8 hours of testing. Material balance information was presented for the feed, glass, and off-gas (limited) streams. TCLP analyses were conducted on the glass product produced. The leach rates for each of the glasses analyzed were well below their regulatory limits. However, only lead failed TCLP analyses of the unvitrified waste material.

2. Wu, S.K. et al. 1992. "Sirosmelt - Modern Smelting for Environmental Compliance." Ausmelt Pty Ltd. Australia.

This report describes processing dusts and residues from lead- and iron-smelting processes. These wastes are mostly iron, lead, and zinc (calcined or uncalcined). The report describes the combined Sirosmelt furnace and Ausmelt lance technologies for treating the waste materials. Coal $(\sim 3 \%)$ and silica $(\sim 20 \%)$ are added to the wastes to provide lead and zinc reduction, and yet produce a pourable slag. The Ausmelt lance is made from steel and is protected beneath the surface of the molten slag by a frozen laver of the slag material. This lance provides fuel and combustion air to the material to obtain operating temperatures of 1300 to $1350^{\circ} \mathrm{C}$. One use of the high zinc fumes (from the high zinc waste materials) is for feedstock in an electrolytic zinc plant. The zinc- and lead-depleted slag from the process is tapped, granulated, and discarded. Since large carryovers into the off-gas are desired for lead, silver, and zinc, decontamination factors near one were maintained for these constituents. The off-gas system used to capture the carryover fume was composed of a spray cooler and a baghouse.

3. Shearer, T. (SITE Demonstration, EPA), Hnat, J.G. et al. (Vortec Corp.), and St. Clair, J. (DuPont). 1992. "Vitrification of Heavy Metal Contaminated Soils with Vortec Corporation's Combustion Melting System (CMS)." I\&EC Special Symposium, American Chemical Society. Atlanta, GA.

The Vortec system was selected in 1991 by the Environmental Protection Agency's (EPA) Superfund Innovative Technology Evaluation (SITE) Emerging Technologies Program (ETP) to demonstrate, using their combustion melting system (CMS), the immobilization of heavy metals in contaminated soils. Surrogates were used in the testing. An EPA-prepared synthetic soil matrix $\left(58 \% \mathrm{SiO}_{2}, 20 \% \mathrm{CaO}\right.$, and $11 \%$ $\mathrm{Al}_{2} \mathrm{O}_{3}$ ) was used at $80 \%$ waste loading and combined with limestone to form the desired product. Glass product criteria were TCLP performance and a $2500^{\circ} \mathrm{F}$ melting temperature. The heavy metals spiked into the soil were arsenic, cadmium, chromium, copper, lead, and zinc. Glass retention of the heavy metals was reported 
along with levels measured in the scrubber and flue gas, however, the mass totals from these three points did not equal the feed mass values in all cases. Cadmium, copper, lead, and zinc mass balances accounted for only $70 \%$ to $80 \%$ of the masses added to the feed. The glass produced during the 6-hour test was reported to have satisfactorily passed TCLP tests. Some mass and energy balance data from this testing was reported.

4. Science Applications International Corp. 1992. "Technology Evaluation Report: Babcock and Wilcox Cyclone Furnace Vitrification Technology." Vol. 1 \& 2. Prepared for the U.S. Environmental Protection Agency, Cincinnati, $\mathrm{OH}$.

The Babcock and Wilcox (B\&W) cyclone furnace was selected by the Environmental Protection Agency's (EPA) Superfund Innovative Technology Evaluation (SITE) Emerging Technologies Program (ETP) to demonstrate (3 runs) the immobilization of heavy metals in contaminated soils. The testing was performed in B\&W's 6-million Btu/hr cyclone furnace at their Alliance facility. This furnace was dry-fed with an auger and the off-gas system was comprised of a scrubber (water filled tank) and a baghouse. Surrogates were used in the testing. An EPA prepared Synthetic Soil Matrix was used, along with spiked concentrations of various materials, to simulate the contaminated soil. Glass residence times in the furnace were expected to be approximately 2 seconds. Glass retention of the heavy metals was reported along with levels measured in the scrubber and flue gas. Each of the glasses produced during the testing was reported to have satisfactorily passed TCLP. Each of the 3 demonstration test runs were reportedly interrupted by operational problems. These problems included clogging in the slag pour throat (cause of aborting the first run), insufficiently melted slag poured from the outlet, Operation and feed line breakage. Detailed mass and energy balance data from this testing was reported.

5. Science Applications International Corp. 1992. "Babcock and Wilcox Cyclone Furnace Vitrification Technology: Applications Analysis Report." EPA/540/AR92/017, Environmental Protection Agency, Cincinnati.

Official report of the previous reference. Additionally, this report provides an economic analysis of the B\&W system for the SITE ETP needs. This analysis involved scaling the 2 ton per day test unit to an 80 ton per day system. Power requirements were expected to increase from $5 \mathrm{MBtu} / \mathrm{hr}$ to $100 \mathrm{MBtu} / \mathrm{hr}$ (natural gas fired). Costs were also estimated for the required excavation, capital equipment, permitting, etc. for a system of this size.

6. Wanger, H. 1993. "Research and Development Report: Melt Testing with Filter Ash, Seiler AG Liebstadt, Switzerland." FEB 511, Von Roll Environmental Technology, Zurich.

This report describes air emissions testing on the vitrification of filter ash performed by Seiler $A G$ in conjunction with the Von Roll company. The system included an $800^{\circ} \mathrm{C}$ gas fired pre-heater which fed into an approximately $1500^{\circ} \mathrm{C}$ gas-fired melt tank (size not given). The glass/slag was then siphoned out of the melt tank. This testing was performed during two different weeks of 1992 . The first week of 
testing was prematurely stopped due to excessive particulate loading in the off-gas stack. This difficulty was addressed for the second week of testing however, offgas pipe plugging still occurred, requiring a reduction in feed rates to one-half to one-third expected rates. No system reliability or life information was reported. Some mass balance information was reported, however, a detailed analysis showing the primary ash constituents was not given but is expected to be primarily alumina based on other published information. Material concentrations given (in the feed, glass, and off-gas) included dioxin, furan, cadmium, mercury, lead, zinc, chloride, sulfates, and sulfites. Additionally, $\mathrm{HCl}, \mathrm{SO}_{2}, \mathrm{O}_{2}, \mathrm{CO}, \mathrm{CO}_{2}$, and $\mathrm{NO}_{\mathrm{x}}$ concentrations were measured in the off-gas. Before exiting the stack, the off-gas was first cooled, then run through a chalk filter which continuously replenished the chalk at an average rate of $18 \mathrm{~kg} / \mathrm{hr}$.

7. Vortec Corporation. 1993. "Phase I Test Results: High Capacity Melter Test Services for Westinghouse Hanford Company, Purchase Order MJB-SVV-096473, Test Dates: July 12-15, 1993." Collegeville, PA.

Vortec performed tests of Hanford low-level waste (LLW) simulants in their combustion melting system (CMS) at the University of Pittsburgh Applied Research Center. Two LLW liquid simulants were processed. These two highly caustic simulants differed only in their nitrate and nitrite levels. The liquid waste simulant was added separately to the unit from the solid glass formers. These formers were comprised of glass cullet and limestone. The report referred to a number of difficulties with pluggages of the liquid feed injector, causing the testing to be extended by two days and early termination in the final stages of testing. Early build-up and plugging difficulties on the injector were thought to be largely due to fuming of the molten glass. A significant reduction in fuming was reported early in the testing by switching to a lower melting glass composition and reducing the operating temperature. However, build-up in the cyclone melter portion of the system during the last portion of the test resulted in the system being shut down. No glass quality information was reported. Detailed mass and energy balance data from this testing was reported.

8. Hnat, J.G. et al. (Vortec Corporation). 1993. "Recycling of Boiler and Incinerator Ash into Value Added Glass Products." Presented at the 1993 Incinerator Conference. Knoxville, TN.

Results of laboratory- and pilot-scale (Vortec's CMS system) vitrification testing were reported for sewage sludge incinerator ash, municipal solid waste (MSW) incinerator ash, and pulverized coal-fired boiler ash. Between 0 and $30 \%$ glassforming additives were added to these waste ashes, which were composed of primarily $\mathrm{SiO}_{2}, \mathrm{Al}_{2} \mathrm{O}_{3}, \mathrm{CaO}$, and $\mathrm{Fe}_{2} \mathrm{O}_{3}$, to reduce the 100 poise temperatures of the final glasses to around $2550^{\circ} \mathrm{F}$. MSW ashes were reported to contain over $6 \%$ $\mathrm{Cl}, 6 \% \mathrm{SO}_{3}$, as well as trace amounts of heavy metals (such as $\mathrm{Cd}, \mathrm{Pb}, \mathrm{Cr}$, etc.). The other waste ashes contained less $\mathrm{Cl}$ and $\mathrm{SO}_{3}$, but similar amounts of heavy metals. TCLP results were reported for both the original waste ashes and the vitrified products. Only the unvitrified MSW waste ashes were shown to exceed TCLP limits, however, all glass products passed this test after vitrification. The pilot-scale testing (CMS) was performed only on the MSW and sewage sludge

Operation

Off - gas

Composition 
ashes. Processing rates of $1000 \mathrm{lb} / \mathrm{hr}$ during the 8 hours of testing were reported. Total particulate emissions ranged from $2.72 \%$ to $4.50 \%$ of the original feed stock. $\mathrm{NO}_{\mathrm{x}}$ and $\mathrm{SO}_{\mathrm{x}}$ emissions were reported and showed that acid gas scrubbing would not be required to meet U.S. regulations. Lead retention in the MSW glasses was reported to range between $25 \%$ to $35 \%$. Venturi scrubber retentions for lead were reported to be between $30 \%$ to $50 \%$.

9. Czuczwa, J.M. et al. (Babcock \& Wilcox Co., Contract Research Division). 1993. EPA/540/R-93/507. "SITE Emerging Technologies Project: Babcock and Wilcox Cyclone Vitrification." U.S.Environmental Protection Agency, Cincinnati, $\mathrm{OH}$.

This report summarizes two phases of testing performed by Babcock and Wilcox for the Environmental Protection Agency's (EPA) SITE Emerging Technologies Program. These two testing phases were performed during 1990 through 1992 (constituting over 15 days of testing) and demonstrated the vitrification of heavy metal-contaminated soils in B\&W's 6-million-Btu/hr cyclone furnace at their Alliance facility. The first phase focused on dry soil processing and the second phase evaluated processing the same material with approximately $20 \%$ added water. The testing involved processing noncontaminated soils (EPA's synthetic soil matrix simulant) before running them with the spiked contaminants (namely $\mathrm{Cd}, \mathrm{Cr}$, and $\mathrm{Pb}$ ). Some materials balance information was given in addition to off-gas $\left(\mathrm{O}_{2}, \mathrm{CO}\right.$, $\mathrm{CO}_{2}$, and $\mathrm{NO}_{\mathrm{X}}$ ), and TCLP data. Each of the glasses produced during the testing was reported to have satisfactorily passed TCLP. For the last portion of phase 2 testing, $10 \%$ borax was added to the feed to attempt to increase the retention of heavy metals. The effects of this addition (for a constant feed rate) were a decrease in load on the cyclone from 4.9 to $4.1 \mathrm{MBtu} / \mathrm{hr}$, a reduction in slag processing temperature from 2430 to $2320^{\circ} \mathrm{F}$, a decrease in $\mathrm{NO}_{\underline{x}}$ production from 318 to 337 $\mathrm{ppm}$ to $260 \mathrm{ppm}$, and an increase in solids (flyash) carried over in the off-gas from $\simeq 2.5 \%$ to $3.5 \%$ (thought to be due to sodium vaporizing from the borax). The borax addition was reported to not have significantly improved the heavy metals capture in the vitrified slag.

10. Vortec Corporation. 1994. "Vortec Corporation Expression of Interest in Advanced Vitrification Technology Applied to Low-Level Tank Waste Remediation." Collegeville, PA.

This report summarizes Vortec's proposal for participating in the Hanford LLW vitrification evaluation. The unique features of the system were described to be the energy cost effectiveness, small size, independence from the electrical conductivity of the waste stream, ability to process both inorganic and organic waste streams, rapid startup and shutdown capability, ability to accommodate waste composition variations, ability to operate at negative pressures, and low $\mathrm{NO}_{x}$ productions due to staged combustion and rapid quenching. The company's present facilities were described, including their 10 to 20 ton per day CMS unit in Harmarville, PA. Some scale-up information was discussed. Previous waste stream treatment demonstrations were described to include waste ashes, contaminated soils and Hanford simulated low-level tank wastes. 
TABLE 3.1. OPERATIONAL AND PERFORMANCE DATA FOR COMBUSTIONHEATED MELTERS

The following notations and abbreviations apply to the Table 3.1.

NA - Not Applicable

[] - Fraction Accumulated in Melter

NR - Not Reported

* - Calculated from Glass Analyses, Not Off-Gas

" " - Based on Target Values 


\begin{tabular}{|l|l|}
\hline Company \\
Melter \\
Test Name \\
Feed Description \\
Reference(s) \\
Energy Source \\
Power (kW-h/kg glass) \\
Glass Temp (oC) \\
Feed On' Time \\
Feed Rate (kg/h) \\
Glass Prod Rate (kg/h) \\
Off-gas Solids $(\%$ of feed) \\
Feed Type \\
Feed Composition: \\
$\mathrm{Ag}$ \\
$\mathrm{Al}$ \\
$\mathrm{As}$ \\
$\mathrm{B}$ \\
$\mathrm{Ba}$ \\
$\mathrm{Bi}$ \\
$\mathrm{C}$ \\
$\mathrm{Ca}$ \\
$\mathrm{Cd}$ \\
$\mathrm{Ce}$ \\
$\mathrm{Cr}$ \\
$\mathrm{Cs}$ \\
$\mathrm{Cu}$ \\
$\mathrm{Fe}$ \\
$\mathrm{Ge}$ \\
$\mathrm{Hf}$ \\
$\mathrm{Hg}$ \\
$\mathrm{K}$ \\
$\mathrm{La}$ \\
$\mathrm{Li}$ \\
$\mathrm{Mg}$ \\
$\mathrm{Mn}$ \\
$\mathrm{Mo}$ \\
$\mathrm{Na}$ \\
$\mathrm{Nd}$ \\
$\mathrm{Ni}$ \\
$\mathrm{P}$ \\
\end{tabular}

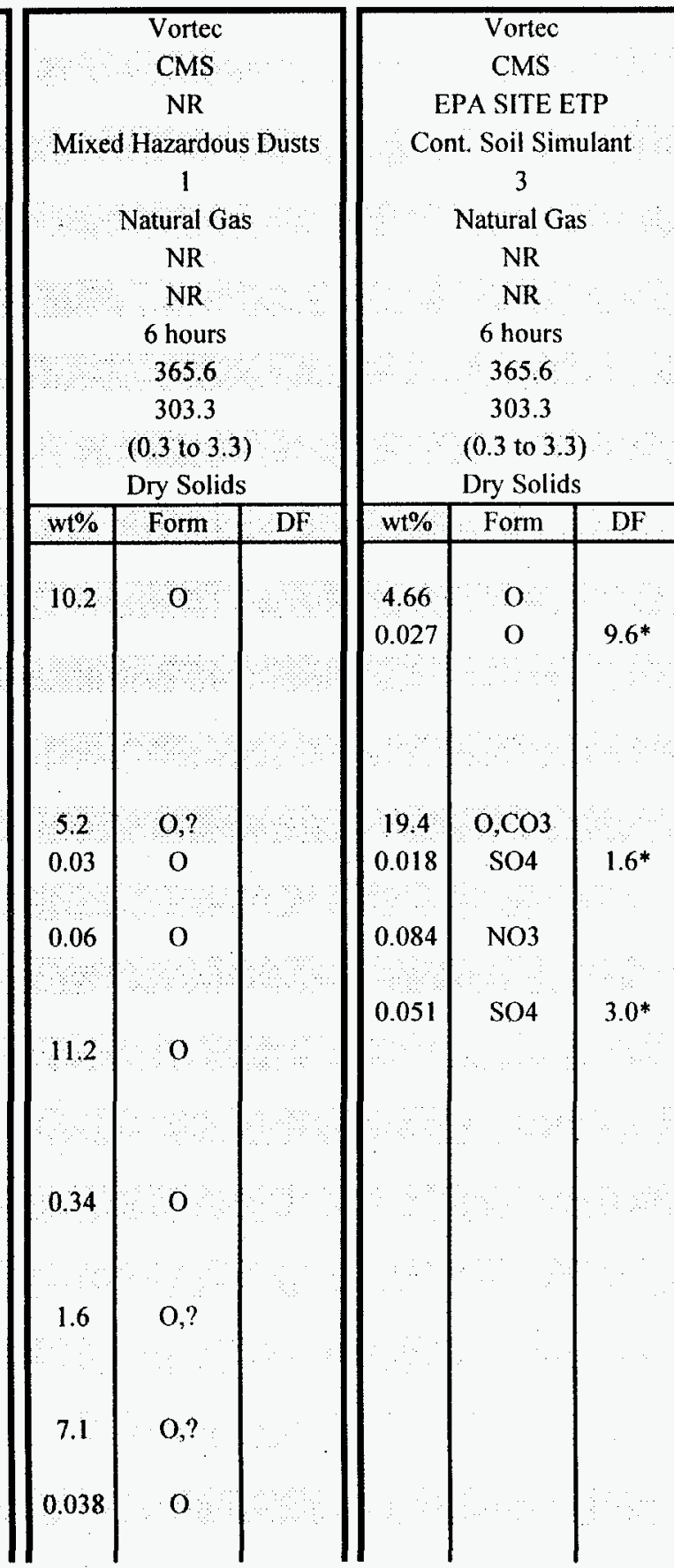

\begin{tabular}{|c|c|c|}
\hline \multicolumn{3}{|c|}{$\begin{array}{c}\text { Babcock \& Wilcox } \\
\text { Cyclone Furnace } \\
\text { EPA SITE ETP \#1 } \\
\text { Cont. Soil Simulant } \\
4,5 \\
\text { Natural Gas } \\
18.80 \\
1319 \\
>6 \text { hours } \\
77.1 \\
\text { NR } \\
3.28 \\
\text { Dry Solids } \\
\end{array}$} \\
\hline $\mathbf{w} \mathbf{1} \%$ & Form & DF \\
\hline 6.69 & 0 & \\
\hline 0.393 & $?$ & $1.4^{*}$ \\
\hline 10.5 & 0 & \\
\hline 0.126 & $?$ & $1.1^{*}$ \\
\hline 0.45 & $?$ & $4.1^{*}$ \\
\hline 3.0 & 0 & \\
\hline 1.15 & 0 & \\
\hline 2.6 & 0 & \\
\hline 0.5 & 0 & \\
\hline 0.061 & O & \\
\hline
\end{tabular}

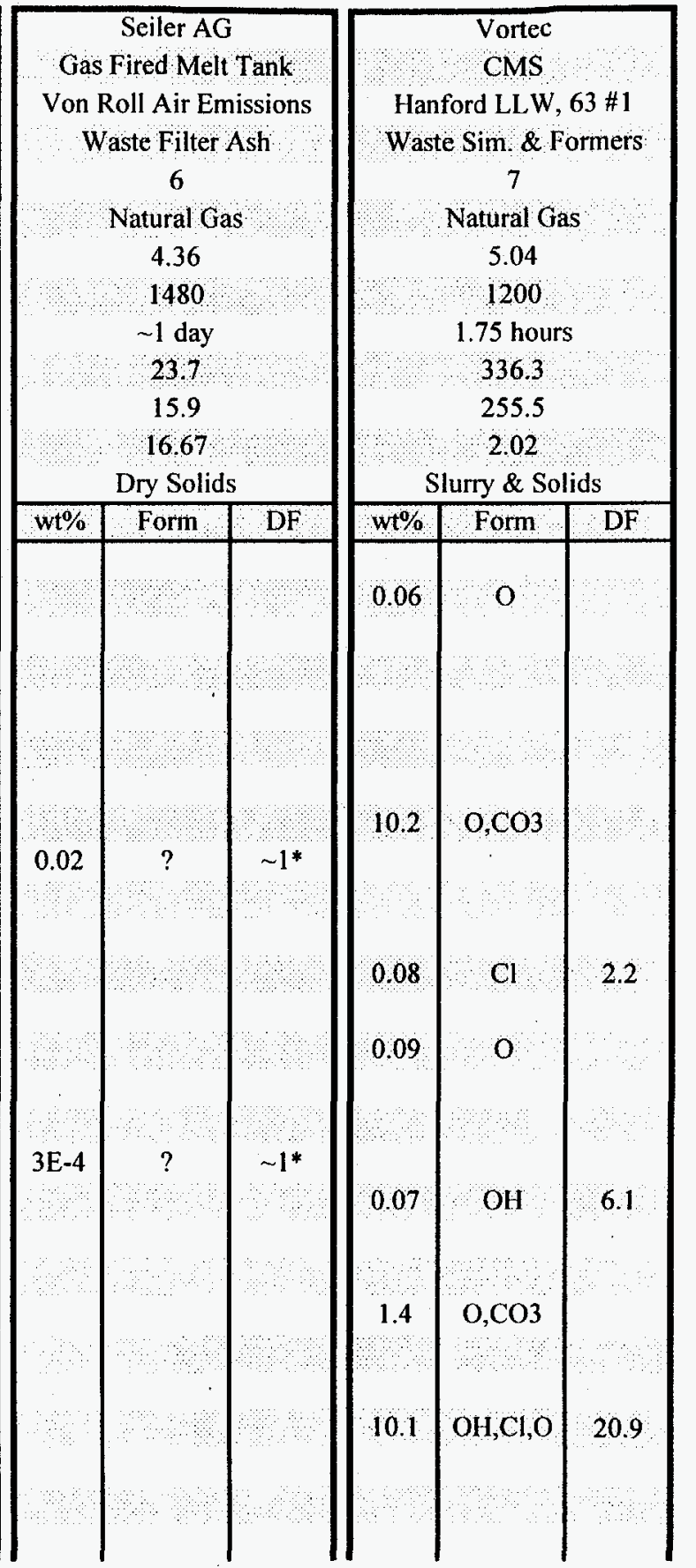




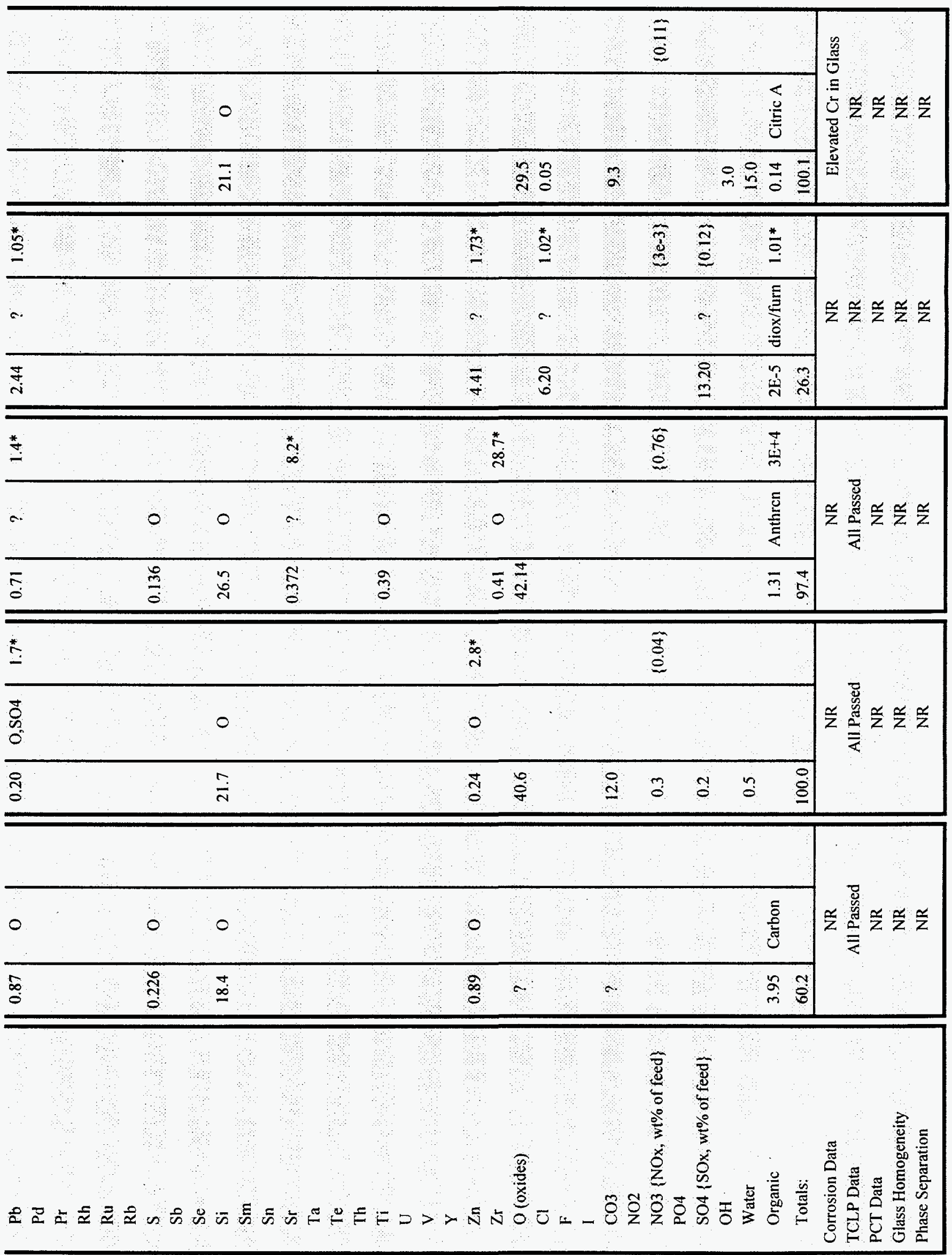




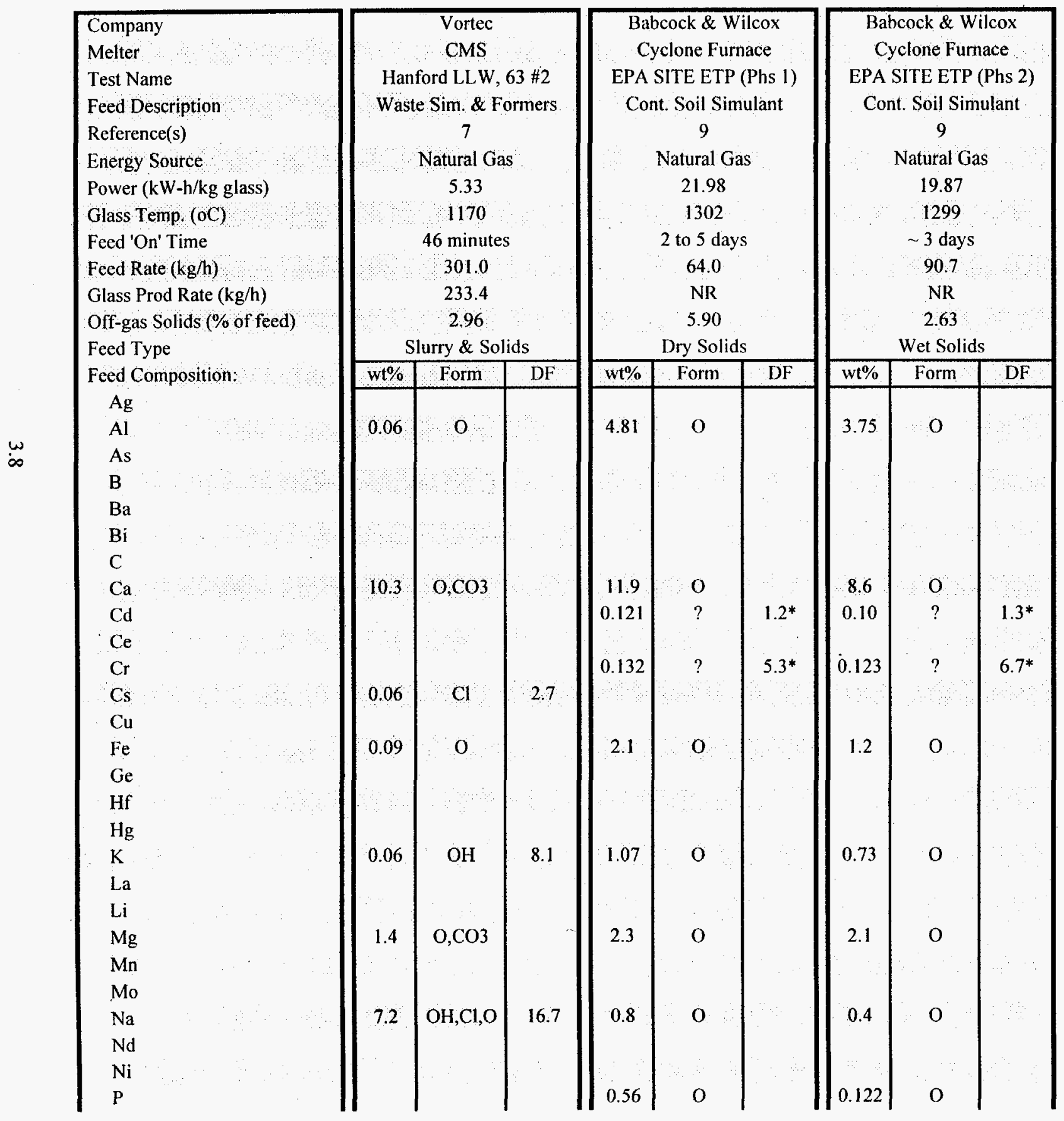




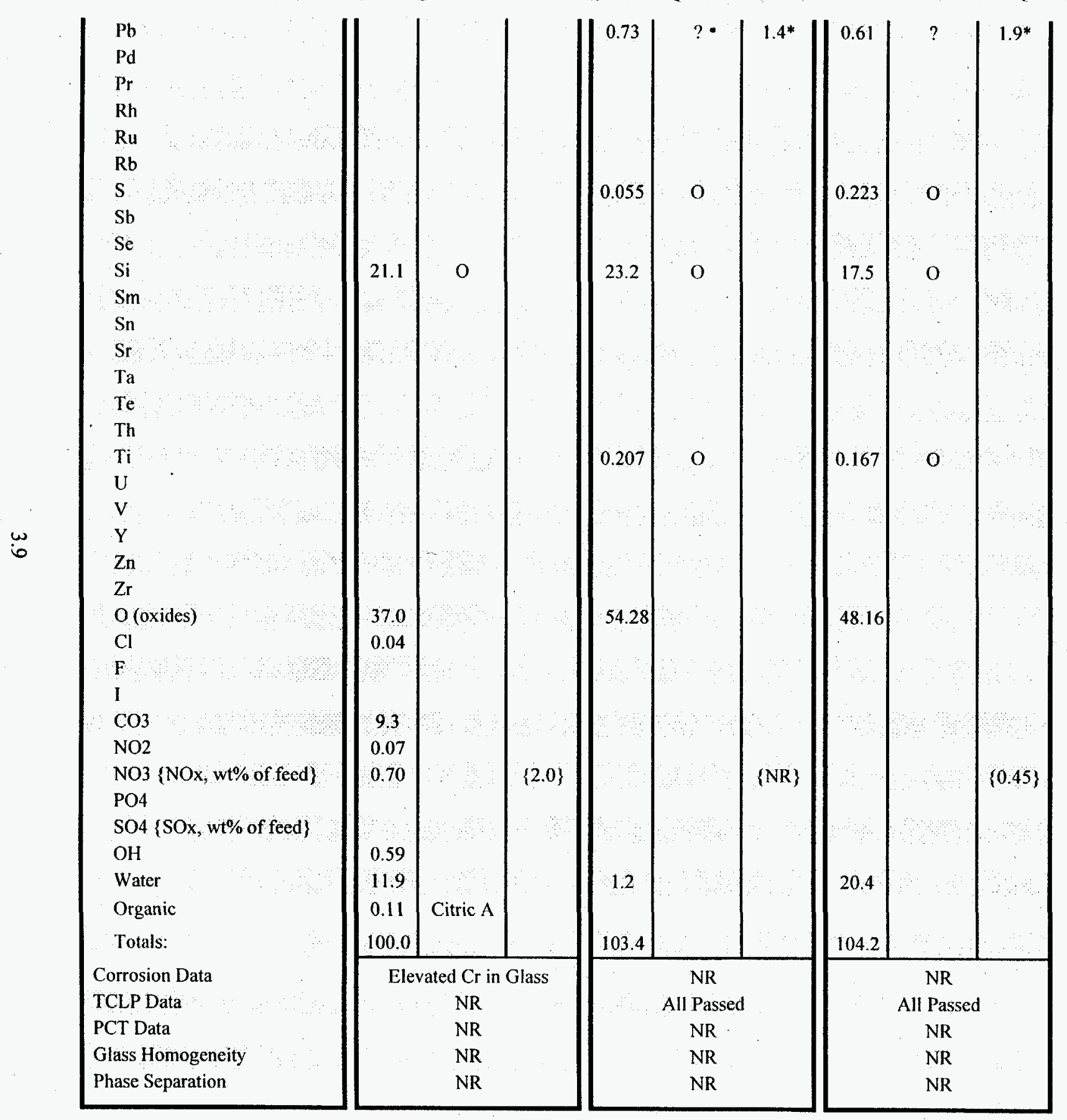




\subsection{ANNOTATED BIBLIOGRAPHIES OF VITRIFICATION LITERATURE}

1. Ferguson, R.B., et al. 1980. DP-MS-80-60: "A Small-Scale Integrated Demonstration of High-Level Radioactive Waste Processing and Vitrification using Actual SRP Waste." Savannah River Laboratory. Aiken, SC.

Proposed methods for pretreatment and processing of Savannah River Plant waste are described, although the report does not include any actual processing data. Limited information about the melter design is provided. The melter cavity is rectangular, about $23 \mathrm{~cm}$ long, and its approximate power requirement is $2.5 \mathrm{~kW}$.

2. Woolsey, G.B., et al. 1981. DP-MS-81-4: "A Small-Scale Integrated Demonstration of High-Level Radioactive Waste Processing and Vitrification Using Actual SRP Waste." Savannah River Laboratory. Aiken, SC.

This paper describes an integrated system for processing small quantities of actual high-level waste at the Savannah River Plant. The system consists of eight major unit operations, each briefly described in the paper. Actual operating data are not provided.

3. Woolsey, G.B. and Plodinec, M.J. 1981. DP-MS-81-54: "Vitrification of High-Level Radioactive Waste in a Small-Scale Joule-Heated Ceramic Melter." Savannah River Laboratory. Aiken, SC.

A small-scale melter has been operated at the Savannah River Laboratory since early 1979, processing actual Savannah River Plant waste. The melter was fed a slurry with a $30-w t \%$ solids content, of which approximately $10 \%$ was waste and $20 \%$ was frit. Compositions are provided for the individual waste and frit, but not for the combined feed. Volatility data are presented for a few radioactive species as follows (\% volatilized): Cs-137: 1\%, Ru-106: 5\%, Tc-99: 2\%, Sr-90,5\%. The melter capacity is stated to be approximately $1 \mathrm{lb} /$ hour, but it is not specified whether the capacity is for glass or feed. No other operating data are presented.

4. Sevigny, G.J. October, 1981. "PSCM-3 Run Summary." Pacific Northwest Laboratory. Richland, WA.

The third run of the Pilot-Scale Ceramic Melter (PSCM) was completed in July 1981 , producing about $2500 \mathrm{~kg}$ glass from simulated Savannah River waste. The main objective of this run was to assess the feed characteristics and its processing behavior in the melter. A complete set of composition and characterization data are provided for feed, glass, and off-gas samples, as well as melter operating parameters. At the end of the run, the melter was drained and examined. A sludge layer 1 to 2" thick had accumulated on the bottom of the melter during all three PSCM runs. Within the sludge laver were white walnut-sized and pea-sized nodules, as well as metal-like crystalline material accumulations. No information is provided on the compositions of these materials. 
5. Author, date unknown. "PSCM-4 Run Summary." Pacific Northwest Laboratory. Richland, WA.

The fourth run of the PSCM was completed in December 1981 after 107 hours of continuous operation. This run processed 6150 liters of the same feed used in the PSCM-3 run, with only minor modifications in some trace elements, and produced $2709 \mathrm{~kg}$ of glass. The feed processing rate averaged $25.3 \mathrm{~kg} / \mathrm{hr}\left(35.6 \mathrm{~kg} / \mathrm{hr}^{\circ} \mathrm{m}^{2}\right)$ and reached a maximum of about $32 \mathrm{~kg} / \mathrm{hr}\left(45 \mathrm{~kg} / \mathrm{hr}^{\circ} \mathrm{m}^{2}\right)$ before becoming unstable. The average electrode power requirement was $82 \mathrm{~kW}$ to maintain a glass temperature of $1150^{\circ} \mathrm{C}$. The average off-gas flow rate was 70 SCFM (150 ACFM) with a maximum surge flow of 145 SCFM (304 ACFM). Melter DFs for this run were very similar to the DFs in the PSCM-3 run for most elements. The most notable exceptions were for cesium (DF $=12$ compared to 3.8 ) and tellurium (DF $=2$ compared to 32). Also, a DF of 6 for cadmium was measured in this run that was not determined in the PSCM-3 run. Corrosion coupons of various materials were placed in the plenum before the run, and removed and examined after the run. Discussions of these short-term test results are provided.

6. Dierks, R.D. March, 1982. "PSCM-5 Summary." Pacific Northwest Laboratory. Richland, WA.

The fifth run of the PSCM was completed in January 1982, processing the same feed used in the PSCM-3 and PSCM-4 runs. Approximately 7127 liters of feed was processed over nearly 100 hours, producing $3338 \mathrm{~kg}$ of glass. Plenum heaters were used to boost the processing rate in an attempt to achieve a maximum rate. During maximum steady state operations, the average processing rate was $39 \mathrm{~kg} / \mathrm{hr}(53$ $\mathrm{kg} / \mathrm{hr}^{\prime} \mathrm{m}^{2}$ ) with $95 \mathrm{~kW}$ electrode power and $36.5 \mathrm{~kW}$ plenum heater power. The bulk glass temperature averaged $1130^{\circ} \mathrm{C}$. Two samples taken from the off-gas stream indicated that the total melter entrainment ranged from $0.15 \%$ to $0.27 \%$. At the time the report was written, DF data for individual elements were not available. Corrosion coupons were put into the melter before the run and examined afterwards. The results of these short-term tests are provided.

7. Brown, et al. 1983. "Savannah River Laboratory's Operating Experience with Glass Melters." Proceedings of the ANS Topical Meeting on the Treatment and Handling of Radioactive Wastes, pg. 191. April 19-22, 1982. Richland, WA.

The first large-scale melter tested at Savannah River was the Project 1941 melter, which was started in 1980 . This melter was later referred to as the Calcine Fed Melter (CFM). It was designed with Monofrax K-3 refractory enclosed in a watercooled stainless steel shell, and had a $1.1-\mathrm{m}^{2}\left(11.75-\mathrm{ft}^{2}\right)$ glass surface area. The bulk glass temperature was maintained for 398 days at approximately $1130^{\circ} \mathrm{C}$ using rodtype Inconel-690 electrodes. The melter was both calcine-fed and slurry-fed during this time and produced 74 tons of glass during 10 runs. Production rates varied, depending on feeding method and supplemental heating. Values ranged from 31 $\underline{\mathrm{kg} / \mathrm{hr}^{-\mathrm{m}^{2}}}$ for slurry feeding with no supplemental heating, to $171 \mathrm{~kg} / \mathrm{hr}^{2} \mathrm{~m}^{2}$ for calcine feeding with supplemental heating. During processing, there were problems of spinel accumulation on the melter floor, primarily caused by maintaining a glass

Operation

Off - gas

Corrosion

Operation

Off - gas

Corrosion

Operation

Phase Sep. 
temperature below the liquidus near the melter floor. The average corrosion rate of Inconel 690 electrodes and thermowells was $12.7 \mu \mathrm{m} / \mathrm{day}$. Monofrax K-3 showed a maximum corrosion rate of $70 \mu \mathrm{m} /$ day. This report does not include any data on feed/glass compositions, off-gas characteristics, or utility requirements.

8. Goles, R.W. and Sevigny, G.J. 1983. "Off-gas Characteristics of Defense Waste Vitrification using Liquid-Fed Joule-Heated Ceramic Melters." Pacific Northwest Laboratory. Richland, WA.

This report summarizes 11 tests conducted in the Pilot-Scale Ceramic Melter (PSCM, 0.73- $\mathrm{m}^{2}$ exposed glass surface area, tests 1 through 8 ) and Liquid-Fed Ceramic Melter (LFCM, 1.05- $\mathrm{m}^{2}$ exposed glass surface area, tests 4,6 and 7). These tests spanned 3 years (1980 through 1982) and studied slurry feed processing of Savannah River Project DWPF high-level waste simulants. The tests ranged from 99 to 232 hours. The electrodes for both of these melters were made from Inconel690 and some tests were performed with electric plenum heaters (PSCM-5,6, \&8 and LFCM-4,6, \& 7) and one test (PSCM-2) with a gas-fired torch plenum heater. The PSCM-1 \& 2 and LFCM-4 \& 6 tests were run with "alkaline" feeds (pH 11 to 12) and all of the other tests were run with "acidified" feeds (adjusted with formic acid to $\mathrm{pH} 5$ to 6). The primary difference in the off-gas for each feed type was increased $\mathrm{CO}$ and $\mathrm{CO}_{2}$ emissions with the formated feed, as was expected. All of the aerosol size distributions, except from PSCM-4, were bimodal with the main distributions averages $<1 \mu \mathrm{m}$ (noted to be primarily, $\sim 83 \%, \mathrm{NaCl}$ ) and $>16 \mu \mathrm{m}$ in diameter. Total aerosol DFs across the melter were compared between plenum temperature boosting and nonboosting tests (PSCM-6 and PSCM-5, respectively). This comparison showed no significant differences in melter emissions when boosting or not. After the testing, the melter was drained and a metallic slag was observed on the bottom. Although the slag was not quantified, it was composed mostly of nickel with some amounts of ruthenium, selenium, and tellurium. $\mathrm{Na}_{2} \underline{\mathrm{SO}}_{4}$ formations were also observed floating on the glass surface during testing (believed to be only half the inventory, the other half leaving with the off-gas). Estimates were made to show that at feed concentrations less than $\sim 0.025-\mathrm{wt} \% \mathrm{Na}_{2} \mathrm{SO}_{4}$ these accumulations should not form. These observed phase separations were presumed to be a result of some of the highly reducing SRL feed blends.

9. Crow, K.R., et al. May, 1983. DPST-83-558: "Summary of Campaign 1 of the Small Cylindrical Melter-2." Savannah River Laboratory. Aiken, SC.

The second generation Small Cylindrical Melter-2 (SCM-2) began operations in June, 1982, and the first testing campaign continued through January, 1983. During that time, 4.9 metric tons of glass were produced from 11,090 liters of slurry feed (combinations of frit-131, frit-165, and simulation-2 waste). The melter was designed with three different-sized electrodes, and had both a jet-controlled freeze valve bottom drain and a differential pressure overflow pouring system. Individual melt rate tests were performed during the campaign to assess effects of various operating parameters on specific melt rate. An air bubbler (sparger) was tested, resulting in a $2.8 \mathrm{x}$ increase in melt rate (from 26 to $73 \mathrm{~kg} / \mathrm{hr}^{2} \mathrm{~m}^{2}$ ) and corresponding electrode power consumption (from 12 to $22 \mathrm{~kW}$ ). There was also a slightly higher observed corrosion rate. An increase in solids content from $35 \%$ to $43 \%$ also 
increased the melt rate from 31 to $38 \mathrm{~kg} / \mathrm{hr}^{\circ} \mathrm{m}^{2}$. Utility requirements and off-gas and glass characterization data are not included. Thermocouple thermowells were used in the glass and plenum space, and consisted of 1" sch. 40 Inconel-690 pipe. Average corrosion rates reported ranged from 1.8 to $38.4 \mu \mathrm{m} / \mathrm{day}$ for test times from $\underline{58 \text { to } 121 \text { days. }}$

10. Perez, Jr., J.M. June, 1983. "West Valley Melter Experiment Run Summary - PSCM14." Pacific Northwest Laboratory. Richland, WA.

The PSCM was used to perform the first large-scale melter experiment for the West Valley Demonstration Project (WVDP) using Savannah River 131 frit and simulated West Valley alkaline high-level waste. Results from analysis of feed and glass samples are provided in comparison to the target glass composition. The test lasted six days, during which time various experiments were performed with the melter's glass airlift pouring system. The results of these tests are provided, however, melter operating parameters are not included for the run.

11. Perez, Jr., J.M. September, 1983. "West Valley Waste Vitrification Experiment PSCM-15 Summary." Pacific Northwest Laboratory. Richland, WA.

The second large-scale melter experiment for the West Valley Support Project was completed in May 1983 using the PSCM. The main purpose of the test was to assess the behavior of their simulated high-level waste when processed as a slurry in the PSCM. During the 189-hour test, approximately $3550 \mathrm{~kg}$ of glass was produced from a simulate combination of WVDP alkaline (PUREX) and acid (THOREX) wastes along with glass-forming additives. Numerous incidents of foaming in the melter were recorded during the run. The exact cause was not identified, but it appeared to be related to changes in the glass level and glass electrical resistance. Later documents revealed that this foaming may have been primarily due to overoxidation of the glass. As a general rule, the glass temperatures rose to near $1200^{\circ} \mathrm{C}$ during the foaming attributed to the insulating properties of the foam. Compositions of feed, glass, and off-gas samples are provided along with graphs showing trends in melter operating parameters. Results of corrosion testing performed with coupons in the melter are also discussed.

12. Sevigny, G.J. October, 1983. "SRL ESCM-II Run Summary." Pacific Northwest Laboratory. Richland, WA.

Ten days of testing with the experimental-scale ceramic melter (ESCM) was completed in August 1983. The main objectives were to compare the effects of changes in air inleakage and plenum heating on other melter operating parameters. Specifically, the behavior of mercury in the melter was investigated. The test was divided into two parts. Part $\mathrm{A}$ had a $15-\mathrm{lb} / \mathrm{hr}$ air inleakage, plenum heating, and a $700^{\circ} \mathrm{C}$ plenum temperature. Part B had 1.6 - $\mathrm{lb} / \mathrm{hr}$ air inleakage, no plenum heating, and $550^{\circ} \mathrm{C}$ plenum temperature. As expected, the processing rate with plenum heating was higher (about $2 \mathrm{x}$ ). Off-gas and feed sample measurements for elements during periods of steady state showed that the use of plenum heating had a negligible effect on the melter DFs. Some discussion is included on the behavior of mercury in the melter and off-gas systems. 
13. Sasaki, N., et al. 1984. "Solidification of the High-Level Liquid Waste From the Tokai Reprocessing Plant." Proceedings of the American Nuclear Society International Topical Meeting on Fuel Reprocessing and Waste Management. August 26-29, 1984. Jackson, WY.

In March 1982, construction of the full-scale Mock-up Test Facility (MTF) was completed based on the design of the Vitrification Pilot Plant for the Tokai reprocessing plant. The MTF melter had a glass production capacity of $280 \mathrm{~kg} /$ day, and operated at 1100 to $1200^{\circ} \mathrm{C}$. The refractory material was $\mathrm{AZS}$, and the electrodes are made of Inconel-690. By 1983, five campaigns had been completed, including the processing of $12 \mathrm{~m}^{3}$ of simulated HLLW containing noble metals. The expected total noble metals content in the glass was $1.23 \mathrm{wt} \%\left(\mathrm{RuO}_{2}+\mathrm{Rh}_{2} \mathrm{O}_{3}+\right.$ PdO). The report mentions that the melter was adversely affected by the accumulation of noble metals, however data was not provided regarding the quantities accumulated or the specific changes in the melter's operating behavior. In addition to testing with the MTF, laboratory-scale radioactive vitrification tests were performed in the Chemical Processing Facility (CPF). Six runs were completed from December 1982 to March 1984, processing a total inventory of about $4600 \mathrm{Ci}$.

14. Kessler, J.L. and Randall, C.T. March, 1984. "Performance of a Large-Scale Melter and Off-Gas System Utilizing Simulated SRP DWPF Waste." Proceedings of the Symposium on Waste Management at Tucson, Arizona. pg. 279 - 284. Tucson, AZ.

A review of melter operations on two large-scale melters at Savannah River is provided. This includes a discussion of differences in design features and corresponding improvements. Reported corrosion rates for glass contact materials in the 1941 melter were $0.5 \mathrm{~cm} / \mathrm{vr}(13.7 \mu \mathrm{m} / \mathrm{day})$ for Inconel-690 and $2.5 \mathrm{~cm} / \mathrm{vr}$ $(68.5 \mu \mathrm{m} / \mathrm{dav})$ for Monofrax K-3. The actual locations in the melter for these materials was not specified. The individual units of the off-gas system are described, including their functions and some processing results. Cesium DFs were measured for various off-gas system units, and the results are presented in comparison to the target values. For the melter, the measured cesium DF was 40 compared to a target value of 10 . However, melter operating data, such as temperatures and feed/glass compositions, are not provided.

15. Iverson, D.C. and Bickford, D.F. 1985. "Evaluation of Materials Performance in a Large-Scale Glass Melter After Two Years of Vitrifying Simulated SRP Defense Waste." Mat. Res. Soc. Symp. Proc. Vol. 44. Materials Research Society.

Savannah River's second large-scale melter, the large slurry-fed melter (LSFM), completed two years of experimentation in February 1984, producing over 240 tons of glass. The melter was constructed with Monofrax K-3 for the glass contact refractory, and Inconel-690 for the metal components, including side-entering platetype electrodes, thermocouple thermowells, and drain valves. Melter design features included a melt surface area of $1.1 \mathrm{~m}^{2}\left(12 \mathrm{ft}^{2}\right)$, both a bottom freeze valve drain and an overflow system for glass removal, and silicon-carbide heaters for supplemental heating. The melter was operated for 749 days, of which 193 days were spent feeding the melter with slurries of varying composition. An average corrosion rate reported for Monofrax K-3 was $25 \mu \mathrm{m} /$ day. Inconel- 690 electrodes 
were reported to have a maximum corrosion rate of $7.6 \mu \mathrm{m} / \mathrm{day}$ (ignoring the rounding of edges), and an Inconel-690 thermowell had an average corrosion rate of 3 to $5 \mu \mathrm{m} /$ day after 302 days of service. General operational data, including compositions of the feed, glass, and off-gas, temperatures, production rates, utility requirements, etc. was not provided.

16. Klingler, L.M. and Armstrong, K.M. 1985. "Glass Furnace Project Final Report: An Evaluation of Operating Experience for Low-Level Nuclear Waste Processing." Mound (operated by Monsanto Research Corp.) for U.S. Department of Energy contract number DE-AC04-76-DP00053, Miamisburg, $\mathrm{OH}$.

This report describes commercial low-level waste vitrification testing conducted by Mound for the Low-Level Waste Management Program Branch of the Department of Energy. A Penberthy joule-heated glass furnace was used to perform short duration $(\sim 1$ hour $)$ tests on the following waste types: dry active waste, ion exchange resins, filter sludges, and cartridge filters. The furnace ( 7 ' by ?' exposed glass surface area) was reported to operate off of a $150-\mathrm{kW}$ power supply firing four 6" $66^{\prime \prime}$ high purity iron electrodes spanning the narrow dimension of the tank. Glass temperatures of $1300^{\circ} \mathrm{C}$ to $1370^{\circ} \mathrm{C}$ were maintained during operation and at $1000^{\circ} \mathrm{C}$ during idling. The exact feed compositions for each waste were not given/clear (besides radionuclide content) other than that soda-lime glasses were studied during some segments. However, glass retentions for many of the radionuclides were reported for each waste type. Averaged glass retentions for Cs-137. Mn-54 and Co60 were approximately $(53 \%),(70 \%$ to $96 \%)$, and $(74 \%$ to $96 \%)$, respectively. These retentions varied greatly depending upon the feed water content, organic content, etc. Some gamma scan data was presented for various points within the system to show buildups of radioactive species. Depositions of Cs-137, Mn-54 and Co-60 were measured on firebrick near the inlet of the off-gas line. Additionally, $2 x$ glass Co-60 levels were measured on the refractory floor, indicating separation/pooling of this material. The refractory layout (below the glass surface) consisted of 6" of AZS fuse cast refractory, 4.5" of firebrick, a 0.5 " air gap, followed by $3 / 8^{\prime \prime}$ stainless steel skin. Analysis of this refractory after "more than a year of continuous operation" revealed little refractory wear. A $0.3-\mathrm{cm}$ indentation was reported to be visible at the former glass melt line. Little to no more corrosion was reported during observations made a year later. One of the electrodes was reported to have failed after $\sim 21$ months of operation, resulting in glass pouring from the sidewall penetration. Inspection of all four electrodes revealed only those directly underneath the feed port to be badly corroded. The metal drain (composition not given, heated by passing current through it into the glass melt) was reported to have failed twice in 21 months of furnace operation. This failure rate was confirmed by the manufacturer to be "within the life expectancy for this type of drain."

17. Holton, Jr., L.K., et al. June, 1985. PNL-5393: "Design Features of the Radioactive Liquid-Fed Ceramic Melter System." .Pacific Northwest Laboratory. Richland, WA.

The radioactive liquid-fed ceramic melter (RLFCM) was designed and built to test and verify the operations of the liquid-fed ceramic melter system in an actual radioactive environment. It was designed with internal melting cavity dimensions 
of $61 \mathrm{~cm}$ wide $\times 99 \mathrm{~cm}$ long $\times 99 \mathrm{~cm}$ high; $36 \mathrm{~cm}$ was the normal glass depth. This provided a melt pool surface area of $0.51 \mathrm{~m}^{2}$ and a glass holdup volume of $0.18 \mathrm{~m}^{3}$ ( $500 \mathrm{~kg}$ glass). The melter was designed to operate at slurry feed rates of up to 40 liters $/ \mathrm{hr}$, which provided a mean residence time of greater than 40 hours in the melt cavity at the nominal glass production rate. The glass contact refractory was a 4"thick layer of a Monofrax K-3. This was backed with additional layers of Zirmul paving blocks, Castable Alfrax 66, Fiberfrax Duraboard, and a 1/4"-thick Inconel690 metal containment vessel. Air-cooled Inconel-690 plate electrodes were used to maintain the processing temperature within the range of $1150 \pm 50^{\circ} \mathrm{C}$. Molten glass was poured from the melter through the throat of the discharge section located near the floor of the melt cavity. The molten glass rose through a channel in the refractory into a separate overflow chamber and flowed down an Inconel-690 trough into a receiving canister. The receiving canister was contained and positioned by a canister-handling turntable, which held three canisters, up to $40.6 \mathrm{~cm}$ (16") in diameter and $2.64 \mathrm{~m}$ long. Additional design details on the melter and related systems are provided in the report.

18. Peterson, M.E., et al. June, 1985. "Pilot-Scale Ceramic Melter Nonradioactive Experiment No. 20 (PSCM-20) Summary Report." Pacific Northwest Laboratory. Richland, WA.

From March to April 1985 , the $20^{\text {th }}$ run of the PSCM was completed, processing three types of feeds. The first feed was a glass frit that was used to change over the composition of the bulk glass. The second feed, called "spiked feed," was a slurry simulant with high concentrations of nonradioactive cesium and strontium. This material replaced the glass volume that had been drained and brought the levels of cesium and strontium up to their target values in the glass. The third feed was a simulated Federal Republic of Germany (FRG) slurry, also containing high levels of cesium and strontium. During processing of the FRG feed, approximately $1700 \mathrm{~kg}$ of glass was produced over 218 hours. The maximum feed rate achieved was $34 \mathrm{~L} / \mathrm{h}$ (at $\sim 350 \mathrm{~g}$ oxides $/ \mathrm{L}$ ) with an $80 \%$ cold cap coverage, which was lower than expected. Attempts were made to correlate cesium DF with cold cap coverage. Data indicated that an increase in cold cap coverage tended to suppress cesium volatility, however an actual correlation was not identified because of incomplete data. The cesium DF also appeared to be related to the cesium concentration in the feed. An extensive analysis of the off-gas stream was performed, with a large amount of data presented in the report. This includes compositions and size distributions for the off-gas stream, and elemental DFs for several off-gas treatment units.

19. Allen, T.L. et al. August 1985. DP-1676: "History of the Small Cylindrical Melter." Savannah River Laboratory. Aiken, SC.

The small cylindrical melter (SCM) was the first moderate-sized melter operated at Savannah River. Operations started with this melter in October 1979, and continued until February 1982. During this time, three campaigns were completed, producing just over $\mathbf{2 8 . 6}$ metric tons of glass. This melter was both dry and slurry-fed with various combinations of frit and waste simulant. The melt cavity was lined with Monofrax K-3 with a $0.12-\mathrm{m}^{2}\left(1: 3-\mathrm{ft}^{2}\right)$ melt surface area, and four Inconel-690 
electrodes. During the first campaign, the electrodes were air-cooled and made of two different sizes of schedule 40 pipe, but were replaced for the second two campaigns with solid Inconel- 690 bars that were not cooled. Supplemental heat was provided during feed processing with four silicon carbide globar heaters located in the melter lid. The main objective of the SCM testing was to test the performance of various materials of construction. A discussion of melter components and their operational performance during the melter runs is included in the report. Average corrosion rates of the melter sidewalls constructed of Monofrax K-3 ranged from 46 to $140.5 \mu \mathrm{m} / \mathrm{day}$ (133 and 518 day testing periods). The corrosion rates of the Inconel-690 electrodes were also measured and which ranged from 6.8 to 38.0 $\mu \mathrm{m} /$ day. Operational data includes processing rates and feed compositions, but offgas and glass characterization data are not provided. Some problems were experienced during operations, including electrode failure and accumulations of spinels on the melter floor. These are discussed in the report.

20. Koegler, S. 1986. "Pilot Scale Ceramic Melter, 1985-86 Rebuild." Pacific Northwest Laboratory. Richland, WA.

This document describes the PSCM inspection and rebuild of 1985, which occurred after 58 months of operation and slurry feed testing with multiple feed types (DWPF, West Valley, and HWVP feeds). In total, the melter (with a $0.73-\mathrm{m}^{2}$ exposed glass surface area) had processed over $34,000 \mathrm{~kg}$ of glass since its previous shutdown. The disassembly of the PSCM revealed corrosion information about the Monofrax K-3 glass contact refractories and Inconel-690 electrodes, as well as other melter construction materials. The west wall of the melter was comprised of the following lavers: 4" of K-3 (contacting the glass), 3" of Zirmul brick, 3" of Alfrax66 , and 0.5 " of Duraboard, followed by a water-cooled jacket. During disassembly the maximum K-3 thickness change measured was $\sim 0.9$ " and occurred 7 to 12 " from the melter floor. This location corresponded to just below the glass operating level where glass erosion currents were expected to be the highest. Below this ( 3 to 6" from the floor), K-3 thickness changes were only half this value. This K-3 corrosion information is representative of the other 8 locations measured in the system. The measured total mass decrease of the electrodes (after sand blasting) was $6.8 \%$. The primary areas of attack occurred on the back side of the electrodes near the attached bus and at the electrode feet where significant pitting was observed. The lid refractory experienced significant degradation which resulted in large portions spawling into the glass melt. This was attributed to the expansions of the metal hangars which were attached to the water-cooled lid. These hangers were latter replaced with ceramic versions.

21. Carter, J.T. February, 1987. DPST-87-287: "774-A Research Melter Operation." Savannah River Laboratory. Aiken, SC.

Near the end of 1986 , the $774-\mathrm{A}$ research melter was operated to test chemical conditions in the melter, and produced over $32 \mathrm{~kg}$ of glass in 6 runs of 10 to 12 hours each. Design features of this melter included a cylindrical melter chamber 8 " diameter by 8 " deep, lined with Monofrax K-3 refractory, and four Inconel 690 electrodes. Pouring occurred by manually tipping the melter until glass flowed through the pour spout. Two silicon-carbide heaters located in the melter plenum 
provided supplemental heat for increasing the melt rate. The melter was slurry fed with two types of wastes: Scale Melter Campaign 3 coupled feed (Frit-200) for the first three runs, and mercury-doped sludge-only feed (Frit-165) for the last three. The design glass production rate was $0.77 \mathrm{~kg} / \mathrm{hr}$ with a melt temperature of $1100^{\circ} \mathrm{C}$. During the six runs, production rates ranged from 12.2 to $32.3 \mathrm{~kg} / \mathrm{hr}^{\circ} \mathrm{m}^{2}(0.37$ to $0.97 \mathrm{~kg} / \mathrm{hr}$ ). No additional operating data are provided.

Operation

22. Crow, K.R. et al. March, 1987. DPST-87-247: "Summary of Campaigns SGM-4 and SGM-5 of the DWPF Scale Glass Melter." Savannah River Laboratory. Aiken, SC.

Two additional campaigns of the Scale Glass Melter were completed in December, 1986. A description of the melter and related feed and off-gas systems is provided. Discussions of operating results for individual system components are included as well. Melter feed analyses results are given for both campaigns, however there seems to be a discrepancy in the data and therefore the analyses are not reported here. The values are presented as elemental ppm, but the basis for these numbers is not included. During the two campaigns, about $13,320 \mathrm{~kg}$ of glass were produced over 395 hours of feeding. Specific production rates ranged from an average of 15 to $21 \mathrm{~kg} / \mathrm{hr}^{-\mathrm{m}^{2}}$ to a maximum of $38 \mathrm{~kg} / \mathrm{hr}^{-} \mathrm{m}^{2}$. The feed solids content varied between 32 and $42 \mathrm{wt} \%$. An energy balance was completed during a 6-hour period of steady state operations, where the total energy requirements were shown to be about $217 \mathrm{~kW}$ (123 kW lid heaters, $94 \mathrm{~kW}$ electrodes). Some sampling of the offgas stream was performed and indicated that off-gas entrainment averaged about $0.10 \%$. Additional results from analyses of the off-gas stream are included.

23. Carter, J.T. September, 1987. DPST-87-722: "Research Melter Steady State Operation." Savannah River Laboratory. Aiken, SC.

Two additional runs were completed with the 774-A Research Melter, one lasting 17 hours and the other lasting 42 hours. Descriptions of the feed, off-gas, and glasspouring systems are provided. Data are given only for feed and glass compositions.

24. Guidotti, P.D. et al. September, 1987: DPST-87-532: "Summary of Campaigns SGM-6 and SGM-7 of the DWPF Scale Glass Melter." Savannah River Laboratory. Aiken, SC.

In June 1987, two additional campaigns were completed with the Scale Glass Melter, producing about $23,400 \mathrm{~kg}$ of glass during 582 hours of feeding. The slurry feed solids content ranged from 35 to $49 \mathrm{wt} \%$, producing glass at an average rate of $29 \mathrm{~kg} / \mathrm{hr}^{2} \mathrm{~m}^{2}$ and a maximum of $49 \mathrm{~kg} / \mathrm{hr}^{2} \mathrm{~m}^{2}$. Analysis of the off-gas stream indicated an off-gas entrainment of $0.06 \%$. Analytical results of feed samples taken during SGM-6 are presented, however, the data are incomplete (basis for analysis results is not included) and therefore are not reported. Glass samples were obtained and analyzed, and some of the results are included in the report. As with the feed samples, the basis for the values was not included, resulting in somewhat confusing data which are not reported here. Discussions of the performance of various melter system components are also included. 
25. Edwards, R.E. et al. December, 1987. DPST-87-850: "Summary of Campaign SGM8 of the DWPF Scale Glass Melter." Savannah River Laboratory. Aiken, SC.

The eighth campaign of the scale glass melter was concluded in September, 1987. The melter was dry fed a black frit (165) simulated waste glass and produced 16,800 $\mathrm{kg}$ of glass during the run. The main purpose of this campaign was to achieve the DWPF reference glass-pouring rate of $109 \mathrm{~kg} / \mathrm{hr}$ and to evaluate glass pouring operations at this higher rate. Extensive information is provided on the reference DWPF canister design as well as the melter pouring system. Glass samples were analyzed for composition and compared to the frit specification.

26. Yoshioka, M., April, 1988. DPST-88-491: "Energy Balance on the DWPF Scale Glass Melter; Runs 4-9." Savannah River Laboratory. Aiken, SC.

Five energy balances were completed during four campaigns of the scale glass melter $(4,6,7$, and 9), each taken during approximately 6 hours of steady state operation. Total energy requirements ranged from $212.4 \mathrm{~kW}$ during SGM-7 to $230.5 \mathrm{~kW}$ during SGM-6. Specific energy requirements ranged from 4.5 to 7.2 $\mathrm{kW} \cdot \mathrm{hr} / \mathrm{kg}$ glass, both during SGM-6. Estimates of melter heat losses caused by mass flow, conduction, and radiation are presented for each run, accounting for $94 \%$ to $101 \%$ of the total energy inputs. Various other energy calculations were made, including breakdowns of heat transferred to the cold cap, glass pool, etc. Additional melter operational data are not included with the energy balances for comparison purposes, however, some of this data can be obtained from other run reports.

27. Bickford, D.F., et al. May 1988. DPMS-88-14: "Control of Radioactive Waste Glass Melters: Part 3 - Glass Electrical Stability." Savannah River Laboratory. Aiken, SC.

This report briefly reviews the problems associated with the accumulation of noble metals in melters, and provides data for noble metals tests performed in other countries. It also includes a discussion of the effects of second phases, such as spinels or noble metals, on glass electrical resistivity. Testing was performed to further study the electrical behavior of simulated waste glass under various conditions, and the resulting data are also presented. In addition, the accumulation of noble metals on the melter floor was modeled and used to determine the design features of a melter that might help avoid electrical short-circuiting of the electrodes resulting from this conductive laver. Although the report mentions a melter run, it does not provide any information regarding the specific melter used or the operating conditions.

28. Yoshioka, M., et al. 1989. "Glass Melter and Process Development for the PNC Tokai Vitrification Facility." Proceedings of the 1989 Joint International Waste Management Conference. Volume 2, pg. 13-19. October 22-28, 1989. Kyoto, Japan.

This paper reviews the development and design of the Tokai Vitrification Facility (TVF) melter. Specifications for plant operations include producing glass at a rate of $9 \mathrm{~kg} / \mathrm{hr}$ and maintaining a glass waste oxide loading of $25 \mathrm{wt} \%$. The melt pool surface area was $0.66 \mathrm{~m}^{2}$, and the unit was lined with Monofrax K-3 glass contact refractory. A bulk glass temperature of $1150^{\circ} \mathrm{C}$ was maintained with Inconel 690 
electrodes. Noble metals testing in an un-named full-scale melter with a $45^{\circ}$ sloped bottom is briefly mentioned. Results indicated that the sloped bottom allowed more than $90 \%$ of the noble metals to drain from the melter, however specific data are not provided. Decontamination factors (DFs) of certain feed components were measured during other unidentified full-scale cold testing, and confirmed that actual DFs were greater than the expected values for each piece of equipment in the off-gas treatment system. For the melter, the anticipated DFs were 5 for ruthenium, 20 for cesium, and 200 for strontium. Testing was also performed to determine the optimum form for the glass additives. Frit beads with a nominal diameter of 2 to 2.8 $\mathrm{mm}$ were tested, along with fiberglass frit with fiber diameters of 9 to $12 \mathrm{~mm}$. The fiberglass was sintered into cylindrical forms approximately $70 \mathrm{~mm}$ in diameter by $70 \mathrm{~mm}$ in length, and the liquid waste was absorbed into the frit cylinder. A measurement of the total off-gas particulate during steady state testing showed that the entrainment of particles was 10 times higher using the frit beads compared to the cylindrical fiberglass frit.

29. Holton, Jr., L.K., et al. February 1989. PNL-6790: "Processing Summary Report: Fabrication of Cesium and Strontium Heat and Radiation Sources." Pacific Northwest Laboratory. Richland, WA.

In 1986 and 1987. runs 7 through 9 of the radioactive liquid-fed ceramic melter (RLFCM) were completed, producing 30 canisters of glass each containing an average of 78 to $207 \mathrm{kCi}$ of ${ }^{137} \mathrm{Cs}$ and 85 to $143 \mathrm{kCi}$ of ${ }^{90} \mathrm{Sr}$. These canisters each had resulting decay heat loads averaging 1.5 to $1.9 \mathrm{~kW}$ and average surface exposure rates of 112,000 to $310,000 \mathrm{R} / \mathrm{hr}$. These canisters were produced under a contract for the Federal Republic of Germany to be used as part of a repository testing program. The total estimated glass produced was $5836 \mathrm{~kg}$. The average content of $\mathrm{Cs}_{2} \mathrm{O}$ in the glass ranged from 2.08 to $5.74 \mathrm{wt} \%$, and the SrO average content ranged from 1.65 to $2.67 \mathrm{wt} \%$. After the glass canisters were filled, they were welded, rinsed, inspected for leaks, and decontaminated. This report discusses results of these operations. Each canister was then individually characterized, and an extensive table of this data is presented in an Appendix. Off-gas data are not presented.

30. Choi, A.S. July, 1989. WSRC-RP-89-634: "Freeze and Restart of the DWPF Scale Glass Melter." Savannah River Laboratory. Aiken, SC.

Two final tests were completed as the last campaign of the scale glass melter (SGM). In Test I, the lower electrode power was turned off to simulate complete bypassing of its current through a noble metals layer on the melter floor. For the SGM operating under specified conditions, spinel formation initiated about 24 hours after power loss. In Test II, the melt pool was cooled to below $500^{\circ} \mathrm{C}$ to simulate a prolonged power loss, and the frozen glass was re-heated using the lid heaters only. After power was shut off, it took about 26 hours for the entire glass pool to cool below $500^{\circ} \mathrm{C}$, at which point the lid heaters were turned on. The average cooling rate was $28^{\circ} \mathrm{C} / \mathrm{hr}$. Initially, the melt pool temperatures continued to drop after the lid heaters were turned on, and it took nearly 55 hours before all of the measured glass temperatures began to rise. After 128 hours, glass temperatures were 
considered sufficient and joule heating was initiated. Further discussions and conclusions of both of these tests are included in the report.

31. Goles, R.W. August, 1989. HWVP-89-IVJ0020500D: "Determination of Halogen Content in Glass for Assessment of Melter Decontamination Factors." Pacific Northwest Laboratory. Richland, WA.

This report describes an effort to better quantify halogens (fluoride, chloride, and iodine) in waste glasses. This project was undertaken to provide better melter offgas decontamination factors (DFs), calculated from the glass compositions, for the PSCM-22 and PSCM-23 tests. Several analytical techniques were examined and the most practical method, for the given accuracy was reported to be pyrohydrolysis of the glass, followed by analyses of the scrubbed gases by ion chromatography, spectrophotometric, potentiometric, or mass spectrometric techniques. X-ray fluorescence was reported to be a reasonable analytical method for iodine. To support this recommendation, pyrohydrolysis was used to analyze archived PSCM22 and PSCM-23 glasses. The analyzed glass content of each halogen was converted to melter DFs and compared to those obtained from off-gas measurements made during each of the tests. These values compared well (within $90 \%$ ) for all but the PSCM-22 fluoride values. That comparison showed a difference of $39 \%$. Nevertheless, the conclusion was that the glass analyses supported the DFs already calculated from the off-gas samples. As a result, conservative DF assignments (based on the off-gas analyses) were presented as 4,2 , and 1 for fluoride, chloride, and iodine, respectively.

32. Choi, I.G. September, 1989. WSRC-RP-89-1250: "Effect of Natural Convection on Noble Metal Deposit Rate in a Melter." Savannah River Laboratory. Aiken, SC.

A mathematical model was used to determine the effects of natural convection on the noble metal deposit rate in a joule-heated melter, and to help predict expected deposit rates in the integrated DWPF melter system (IDMS). In a previous noble metal campaign, completed with the $774-\mathrm{A}$ research melter. up to $20 \%$ of the noble metals fed to the melter accumulated on the melter floor. The modeling results indicate that this accumulation resulted from very low velocities in the melter $(0.002 \mathrm{~mm} / \mathrm{sec})$ compared to the expected maximum velocity in the IDMS of 1.76 $\mathrm{mm} / \mathrm{sec}$. The accumulation of noble metals in the IDMS melter is therefore expected to be much lower than observed in the 77.4-A melter.

33. Smith, M.E., et al. November, 1989. WSRC-RP-89-321: "Checkout and Start-up of the Integrated DWPF Melter System." Technical Division, Savannah River Laboratory. Aiken, SC.

The IDMS was a $1 / 9^{\text {th }}$-scale facility started in November, 1988 , and was the fourth large-scale melter system operated to demonstrate the DWPF processes. The melter design was essentially the same as the DWPF design, except an additional 12 " of Monofrax K-3 lined the interior walls of the melt tank, decreasing the diameter from 48 to 24 ". The resulting glass pool surface area was $0.29 \mathrm{~m}^{2}$, and the melter had a design production rate of $11.4 \mathrm{~kg}_{\text {glass }} / \mathrm{hr}$. Two pairs of Inconel 690 electrodes were used to maintain the bulk glass temperature between $1100^{\circ} \mathrm{C}$ and $1150^{\circ} \mathrm{C}$. Two 
Inconel 690 lid heaters were also used during processing and for melter startup. Two methods for glass removal include a bottom drain for emptying the melter, and an overflow pour spout for routing glass pouring. A much more detailed description of the IDMS components and their functions, including the feed, melter, and off-gas systems, is provided in this report. Startup operations of the melter are provided, including descriptions of the initial melter heat-up and processing of the first two batches of melter feed. Very little data are provided for processing the first two batches of feed, and the data provided include only the feed compositions. Because additional information is not provided, such as processing rates or melter operating conditions, this data is not reported.

34. Author unknown. 1990. "Development of Methods for the Vitrification of High-Level Wastes in the USSR." Presented at Spectrum "90. USSR State Committee on the Utilization of Atomic Energy, Russia.

High-level waste vitrification studies with phosphate and borosilicate glasses are presented. Crucible, nonradioactive, and radioactive operations are described. Joule-heated melter(s) were tested using molybdenum, various allovs, and tin dioxide for electrode materials. The pilot-scale facility described processed 100 liter/hr of feed solution with a 400 -g/liter salt content (composition, oxide basis: 22 to $26 \%$ (wt) Na2O, 21 to $25 \% \mathrm{Al} 2 \mathrm{O} 3,47$ to $53 \% \mathrm{P} 2 \mathrm{O} 5$ and 0 to $1.5 \% \mathrm{Fe} 2 \mathrm{O} 3$ ). The glass was produced at $1100^{\circ} \mathrm{C}$ and at a rate of $25 \mathrm{~kg} / \mathrm{hr}$. The following solids losses were reported: $5 \mathrm{wt} \% \mathrm{Ru}-106,0.6 \% \mathrm{Cs}-137$, and 0.2 to $0.4 \% \mathrm{Sr}-90$. The radioactive melter (EhP-500) described used molybdenum electrodes and aluminozircon refractory (Bakor-30), processed at $1200^{\circ} \mathrm{C}$, and had a feed throughput of $400 \mathrm{l} / \mathrm{hr}$ and a power consumption of $2.0 \mathrm{~kW} \cdot \mathrm{h} /$ liter of feed. The "area of melting zone" was $10.7 \mathrm{~m}^{2}$, which is assumed to correspond to the exposed glass surface area. No feed composition data or glass production rate data are given. This unit produced 366 canisters in this unit before being taken out of operation because of failure of the water-cooled power leads to the melter electrodes. Other performance information about various feed preparation units (i.e., calciners, etc.) is given.

35. Goles, R.W., et al. 1990. PNL-7142: "Hanford Waste Vitrification Plant Pilot-Scale Ceramic Melter Test 23." Pacific Northwest Laboratory. Richland, WA.

The 23rd test of the pilot-scale ceramic melter (PSCM) was conducted for 15 days during June 1988. The material processed consisted of Hanford neutralized current acid waste (NCAW) ' 87 simulated waste blended with HW-39-4 frit. The PSCM had an exposed glass surface area of $0.76 \mathrm{~m}^{2}$, used Inconel-690 electrodes, and poured via an air lift assembly. Off-gas exited the melter through a slot-design film cooler then ran through a submerged bed scrubber (total solids DF of 7.4. mostly particles with diameters $>1$ um, and NOx removal $\sim 1 \%$ ), a Chevron demister, a highefficiency mist eliminator (total solids DF of 1400) followed by a HEPA filter. Slurry and glass production rates of $57 \mathrm{liter} / \mathrm{hr}^{\bullet} \mathrm{m}^{2}$ and $28.4 \mathrm{~kg} / \mathrm{hr}^{\bullet} \mathrm{m}^{2}$, respectively, were achieved. To adjust the slurry rheology to acceptable levels and slightly reduce the glass melt to balance the high nitrate concentrations, a total of $24.6 \mathrm{~g}$ of $90 \%$ formic acid per liter of slurry and $10 \mathrm{~g} /$ liter of sugar were added to the feed slurry. A 5-day idling segment at the end of this test revealed semi-volative off-gas

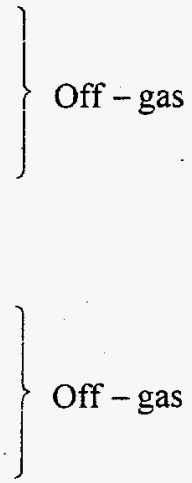


carryovers significantly less than during processing. Coupon corrosion testing of various high-temperature alloys in the melter plenum space revealed Inconel 690 . Incoloy 825, and Haynes 214 to be the least corrosion resistant (tenths of a mil per year).

36. Yoshioka, M. and Takahashi, T. 1990. "Evaluation of Glass Melter Operation Using Highly Simulated Waste for TVF." Proceedings of the International Topical Meeting on Nuclear and Hazardous Waste Management, Spectrum '90. Pg. 296-298. September 30 - October 4, 1990. Knoxville, Tennessee.

In late 1987, the Mock-up Melter III was constructed. This melter is a full-scale melter with the same design as the Tokai vitrification facility (TVF) melter. Noble metals testing was performed with this melter, where approximately 1.37 -wt\% total noble metals in the glass was processed during campaigns 20 and 21. To help avoid the accumulation of noble metals, the temperature of the glass near the bottom of the melter was lowered to $800^{\circ} \mathrm{C}$ to $950^{\circ} \mathrm{C}$ during normal operations. This caused the glass near the bottom to become thick, helping to prevent the noble metal particles from settling through this viscous glass layer. During pouring operations, the bottom glass temperature was increased to $900^{\circ} \mathrm{C}$ to $1050^{\circ} \mathrm{C}$. By using this method of varying the bottom glass temperature, less than $1 \%$ of the total noble metals fed to the melter actually remained in the melter. It is also noted that there were no changes in the glass properties by operating the melter with a lower bottom glass temperature.

37. Kruger, O.L. March, 1990. 24753-89TR-003: "Trip Report on the Technical Information Exchange at the Savannah River Site."

A technical exchange was held at the Savannah River Site in October, 1989. Subjects covered included glass formulation, modeling, and results from minimelter tests performed at Savannah River. A recent noble metals campaign was completed with the 1/100-scale mini-melter (774-A Research Melter) over a period of 13 weeks, processing noble metals at total concentrations of $0.206 \mathrm{wt} \%$ and 0.529 $\mathrm{wt} \%$ in the feed. Test results indicated that 15 to $20 \mathrm{wt} \%$ of the noble metals accumulated on the melter floor, however there were no detectable adverse effects on the electrodes or the electrical behavior of the melter. Additional operating data from these tests are not provided.

38. Ritter, J.A., et al. March, 1990. WSRC-TR-90-131: "Integrated DWPF Melter System Campaign Report Coupled Feed Operation." Savannah River Laboratory. Aiken, SC.

Three IDMS "coupled feed" melter runs were completed in 1989, producing a total of $6,800 \mathrm{~kg}$ of glass. These runs were designed to provide information that would be used as a reference for future testing. During the feed makeup process, samples of the individual feed components (sludge simulant, PHA product, and frit) were analyzed. These data are provided in the report, along with a discussion of the feed makeup procedures and the results of various feed makeup material balances and sample analyses. Final results of the three melter runs are presented, however, the only operational data provided are the feed compositions and power requirements. 
39. Hutson, N.D., et al. May, 1991. WSRC-TR-91-0363: "Integrated DWPF Melter System (IDMS) Campaign Report - Mercury Operation." Savannah River Laboratory. Aiken, SC.

To help characterize the processing of mercury on a large scale, the IDMS was operated from December 1989 to June 1990 with flowsheet levels of mercury added to the feed. Descriptions of the feed makeup process and results are given for the three feed batches prepared, as well as compositions of the individual components of the feed (sludge, frit, PHA). Material balances are completed for mercury in the feed and off-gas systems, but balances are not provided for other feed components. The only other processing data provided are the compositions of the melter feed batches.

40. Hutson, N.D., et al. June, 1991. WSRC-TR-91-0400: "Integrated DWPF Melter System (IDMS) Campaign Report - The First Two Noble Metals Operations." Savannah River Laboratory. Aiken, SC.

Two IDMS melter runs were completed in March 1991 to determine the effects of noble metals on glass melting and melter operations, producing a total of $3260 \mathrm{~kg}$ of glass. The feed makeup components (sludge, frit, etc.) were characterized, and the results are presented along with a data table showing the quantities of noble metals added to the simulant. Analyses of the two feed batches were completed, but the data presented are incomplete in that the analyzed feed compositions do not include the noble metals. Little additional processing data are provided in the report. The primary conclusion based on the two melter runs was that the presence of noble metals greatly enhanced the evolution of hydrogen during the feed makeup process (formic acid addition). The presence of noble metals in the final glass (chemical form and particle size) is also briefly mentioned.

41. Hutson, N.D., et al. October, 1991. WSRC-MS-91-412: "Pilot Scale Processing of Simulated Savannah River Site High Level Radioactive Waste." Savannah River Laboratory. Aiken, SC.

This report presents a review of the IDMS, describing some of the components in the feed preparation and off-gas systems. It mentions six melter runs completed with the IDMS melter, but provides little processing data. The composition of the simulated waste sludge is given, but the total feed and resulting glass compositions are omitted. Decontamination factors (DFs) for cesium were calculated for the melter and off-gas system and then compared to the design values for the DWPF melter. The cesium DF for the melter was 135 compared to the DWPF design value of 6, and the off-gas system cesium DF was 24,000 compared to the design value of 3,000. This report does not include operating conditions of the melter during the time of these DF calculations. 
42. Hutson, N.D. and Smith, M.E. April, 1992. "The Behavior and Effects of the Noble Metals in the DWPF Melter System." Proceedings of the $3^{\text {rd }}$ International Conference of High-Level Radioactive Waste Management. Las Vegas, Nevada. pg. 541-548.

This article provides a general overview of the problems associated with processing noble metals, and some results of noble metals testing performed at Savannah River in the IDMS. Samples of melter feed slurry, melter cold cap, and glass product were analyzed to determine the size, distribution, and chemical form of noble metals. The results of these analyses are briefly discussed. Also, material balances were performed for noble metals in the melter, and it was found that ruthenium was accumulating in the melter at the highest rate, compared to rhodium, palladium, and silver. Although the analytical data results varied, they all indicated that the discharge efficiency for ruthenium was less than $80 \%$. This report does not provide additional melter operational data.

43. Lifanov, F.A., et al. 1993. "Vitrification of Intermediate Level Liquid Radioactive Waste." Presented at the 1993 International Conference on Nuclear Waste Management and Environmental Remediation. Department of Energy Supply, Government of Moscow, Moscow SIA "Radon", Sergiev Posad, Russia.

This report summarizes data from vitrification of intermediate level (3.7x107 $\mathrm{Bq} /$ liter) radioactive wastes from Russia's Kyrskaya and Kalininskaya power stations. The approximate composition (dry basis) of these wastes was $20 \mathrm{wt} \% \mathrm{Na}$. $8.5 \mathrm{wt} \% \mathrm{Ca}, 55 \mathrm{wt} \% \mathrm{NO} 3,1$ to $4 \mathrm{wt} \% \mathrm{SO} 4 \& \mathrm{Cl}$. The melter used was an induction heated "cold-crucible" with $0.16 \mathrm{~m}^{2}$ of exposed glass surface. The waste was blended with glass-forming additives (inorganic sorbent and clinoptilolite) to form a "paste" (some drying in a rotary film evaporator) with a moisture content of 20 to 25 $w t \%$. Operational information included an $1150^{\circ} \mathrm{C}$ melting temperature, induction power frequency of $1.76 \mathrm{MHz}, 22-$ to $30-\mathrm{kg}_{\text {glass }} / \mathrm{hr}$ production rate, $0.7-$ to $1.0-\mathrm{wt} \%$ total solids carryover, 2.9- to $3.5-\mathrm{wt} \%$ total Cs-137 carryover and 4.5- to 6.0$\mathrm{kW} \cdot \mathrm{hr} / \mathrm{kg}_{\mathrm{glass}}$ power consumption. The high sulfate content in the feed produced an insoluble "yellow phase" which was reported to contain 10 times the nuclide (Cs137. Cs-134, $\mathrm{Sr}-90$, etc.) concentration than the glass. Glass $\mathrm{Na}_{2} \mathrm{SO}_{4}$ concentrations were estimated to be 0.8 to $1.1 \mathrm{wt} \%$. The "yellow phase" could not be buried because of its low leach resistance, however, references were made to potentially homogenizing the glass to contain the sulfates, molybdates, chlorides, etc. in a 100to $200-\mu \mathrm{m}$ dispersed phase. Nitric oxide productions were given along with off-gas system performance values.

44. Hutson, N.D. June, 1993. WSRC-TR-92-0403, rev. 1: "Integrated DWPF Melter System (IDMS) Campaign Report - Hanford Waste Vitrification Plant (HWVP) Process Demonstration." Savannah River Laboratory. Aiken, SC.

Two additional melter runs processing noble metals were completed in February, 1992 using the IDMS. Simulated Hanford NCAW '91 waste was vitrified to produce a total of $3614 \mathrm{~kg}$ of glass. During the feed makeup process, samples of the feed at various stages of production were taken and analyzed, as were samples of the off-gases generated. The results of these analyses are presented. During processing of the two feed batches, samples of feed and glass were taken and analyzed to 
perform material balances on all components, including noble metals. However, off-gas analyses were not performed, making it impossible to determine element DFs for the melter. Based on analytical results, it was found that noble metals were accumulating on the melter floor. This accumulation had two major effects on the melter system: a relative decrease in the resistance between the lower electrodes, and an increase in the temperature of the lower electrodes.

45. Perez, J.M., et al. 1994. PHTD-93-04.15D/K963: "HWVP Pilot-Scale Vitrification System Campaign - LFCM-8 Summary Report." Pacific Northwest Laboratory. Richland, WA.

This report summarizes the HWVP-16/LFCM-8 campaign performed at PNL during fiscal year 1993 for processing simulated Hanford NCAW waste slurry. The liquidfed ceramic melter (LFCM) was powered by subsurface Inconel electrodes and had a glass surface area of $1.05 \mathrm{~m}^{2}$. Additionally, this melter was equipped with silicon carbide plenum heaters sheathed in Hanes 214 metal pipe for corrosion resistance. Other system attributes included a vacuum-assisted overflow and a slotted off-gas film cooler. The system operated for 433 hours with an additional 6 hours of down time. A DWPF prototypic system was used to feed the melter. This system consisted of a slurry recirculation loop and a slip-stream to the melter, which flowed through a cross-flow strainer. No substantial problems were reported with this feed system. The average feed rate achieved in the melter (59 liters $/ \mathrm{hr}$ at $450 \mathrm{~g}_{\text {oxides }}$ /liter) was only $64 \%$ to $70 \%$ of the target value. Reported reasons for this poor processing rate were either compositional or effects from the plenum heaters forming an insulative crust on top of the cold-cap. Extensive operational, compositional, and off-gas data was reported. The off-gas treatment system was composed of a submerged bed scrubber (measured total solids DF of 5), a high efficiency mist eliminator (measured total solids DF of 324), and a high efficiency metal filter (measured total solids DF of 105).

46. Hutson, N.D. and Zamecnik, J.R. November, 1994. WSRC-TR-94-0556: "Integrated DWPF Melter System (IDMS) Campaign Report - IDMS Purex 6 (PX6) Operation." Savannah River Laboratory. Aiken, SC.

The report describes a January 1994 campaign completed with the Integrated DWPF Melter System (IDMS) at Savannah River, processing "worst case" levels of noble metals and mercury. The main purpose of the run was to confirm the use of the nitric acid flowsheet with the late wash precipitate hydrolysis process. Mass balance calculations made during the feed makeup process indicated losses of aluminum and copper, which have not yet been accounted for. Off-gas generation was monitored during feed makeup, and the analytical results are presented. A glass sample taken after 2.4 melter volumes had been processed was submitted for a 7-day product consistency test (PCT) and did not meet the acceptance criteria because of phase separation. It was later determined that the feed material was low in waste sludge. Remediation of the feed with additional sludge, aluminum nitrate, and sodium hydroxide resulted in a glass that did meet the PCT acceptance criteria. The only processing data included in the report is the analytical results of feed samples, which do not include the minor components such as noble metals. Analyses of glass 
and off-gas samples are not provided, nor is there any melter temperature or feed processing rate data.

47. Perez, J.M., Shafer, P.J., and Buchmiller, W.C. November, 1994. PVTD-C9503.01A: "Test Results of Vitrifying TWRS DSSF Low-Level Waste Simulant, SmallScale High-Temperature Melter Test 3 (SSHTM-3)." Pacific Northwest Laboratory. Richland, WA.

In August 1994, testing was conducted in the small-scale high-temperature melter (SSHTM), processing simulated Hanford double-shell slurry feed (DSSF) low-level waste (LLW) slurry. The total test time was 111 hours, producing $650 \mathrm{~kg}$ of glass. The SSHTM had a $0.21-\mathrm{m}^{2}$ glass surface area and molybdenum electrode components to achieve glass temperatures in excess of $1500^{\circ} \mathrm{C}$. The off-gas exiting the melter flowed through a porous metal film cooler, and into an ejector venturi scrubber (EVS), followed by a high-efficiency mist eliminator (HEME). Glass pouring was achieved with an inductively heated molybdenum bottom drain. During the run, feed at varying oxide loadings was processed to determine an optimum value. The maximum glass production rate achieved was $52 \mathrm{~kg} / \mathrm{hr} \cdot \mathrm{m} 2$. This rate corresponded to a feed slurry with an oxide loading of $650 \mathrm{~g} /$ liter and a bulk glass temperature of $1350^{\circ} \mathrm{C}$. Off-gas measurements were made for both condensable and noncondensable gases as well as entrained particulate. Volatility appeared to be quite high because of the extensive fuming observed from the cold cap and the glass. This was thought to be largely due to low cold-cap coverages, which averaged around $50 \%$. There was a significant amount of fuming that occurred during glass pouring, and a white powdery substance accumulated on the inside of the glass disposal drums. Also, similar white deposits were observed in the off-gas lines between the film cooler and the EVS during a post-test inspection. Similar deposits had also accumulated in the HEME. These substance were analyzed and found to contain significant fractions of sodium and boron. The DF values for sodium and boron were measured to be 140 and 243 , respectively. No materials corrosion data were presented. 
TABLE 4.1. OPERATIONAL AND PERFORMANCE DATA FOR JOULE-HEATED MELTERS

The following notations and abbreviations apply to the Table 4.1.

NA - Not Applicable

[] - Fraction Accumulated in Melter

NR - Not Reported

* - Calculated from Glass Analyses, Not Off-Gas

" " - Based on Target Values 


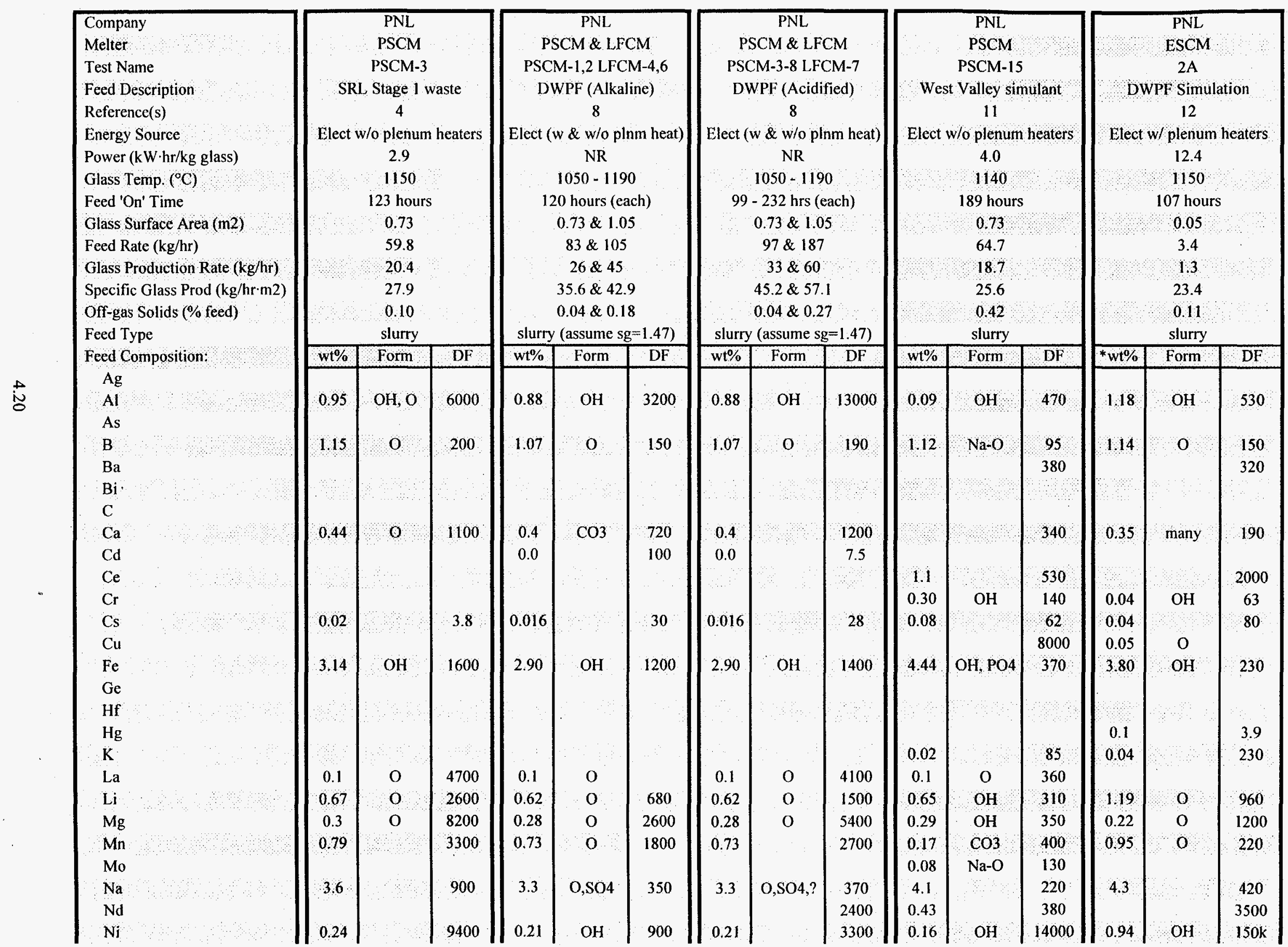




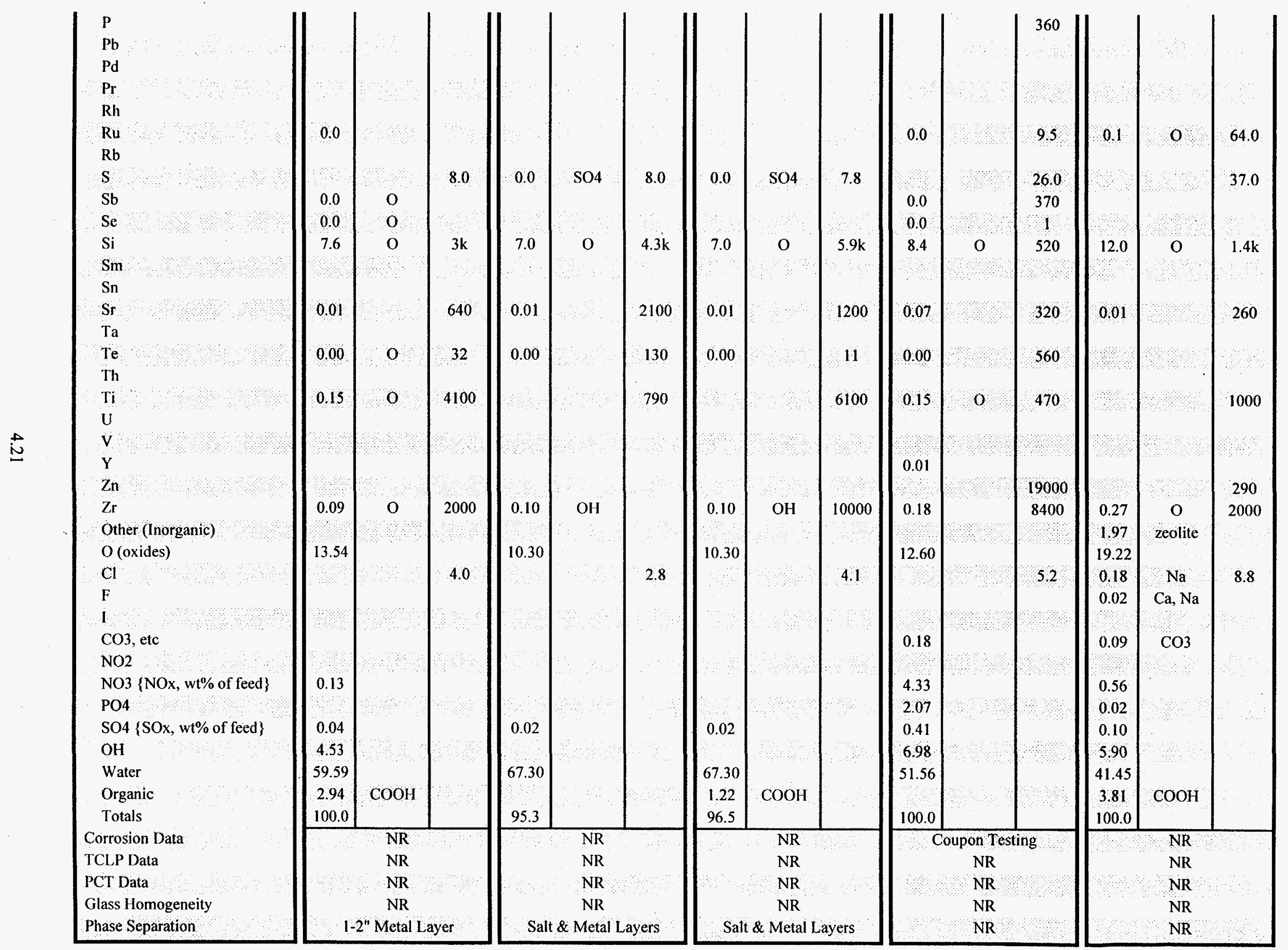




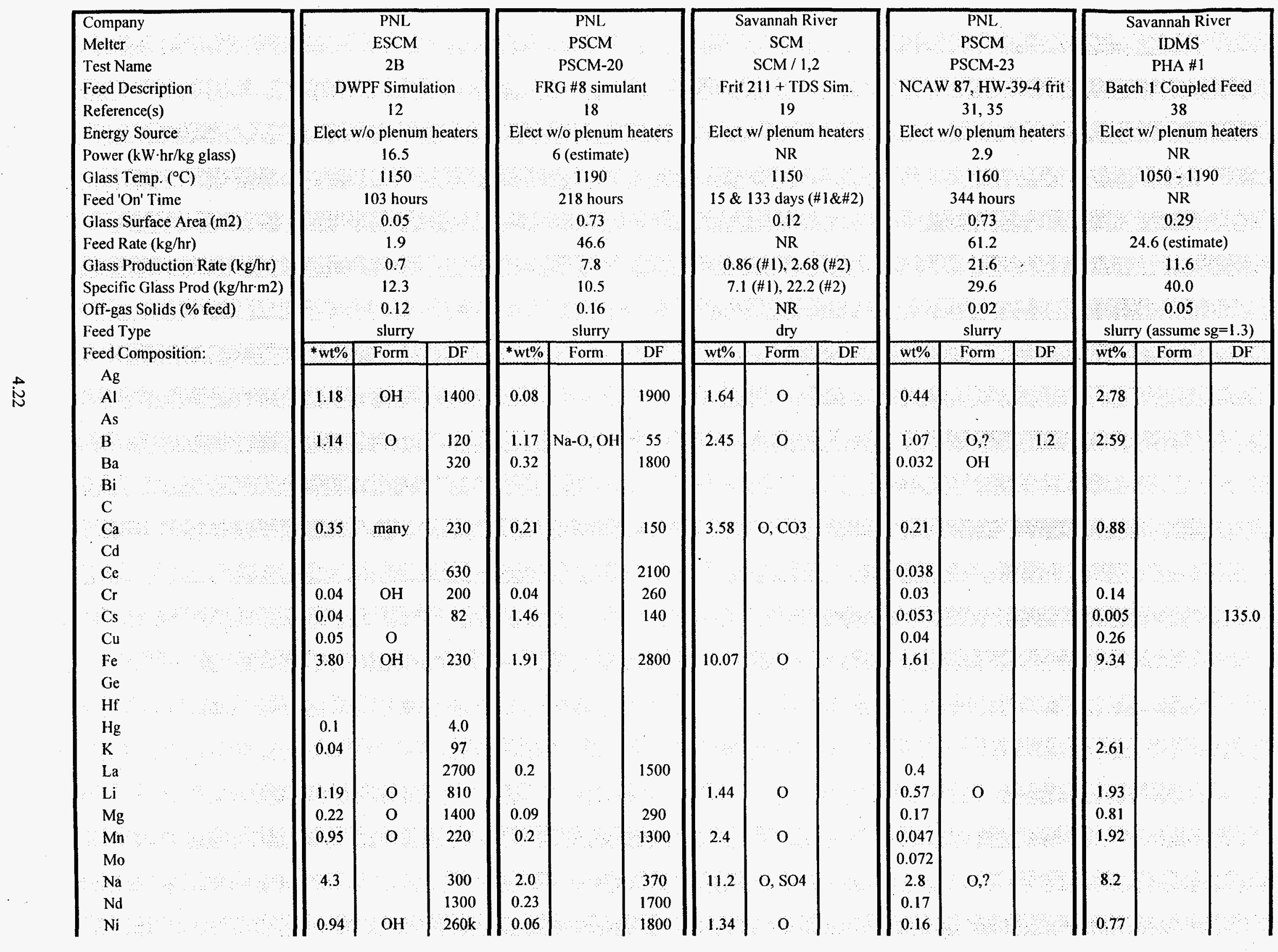




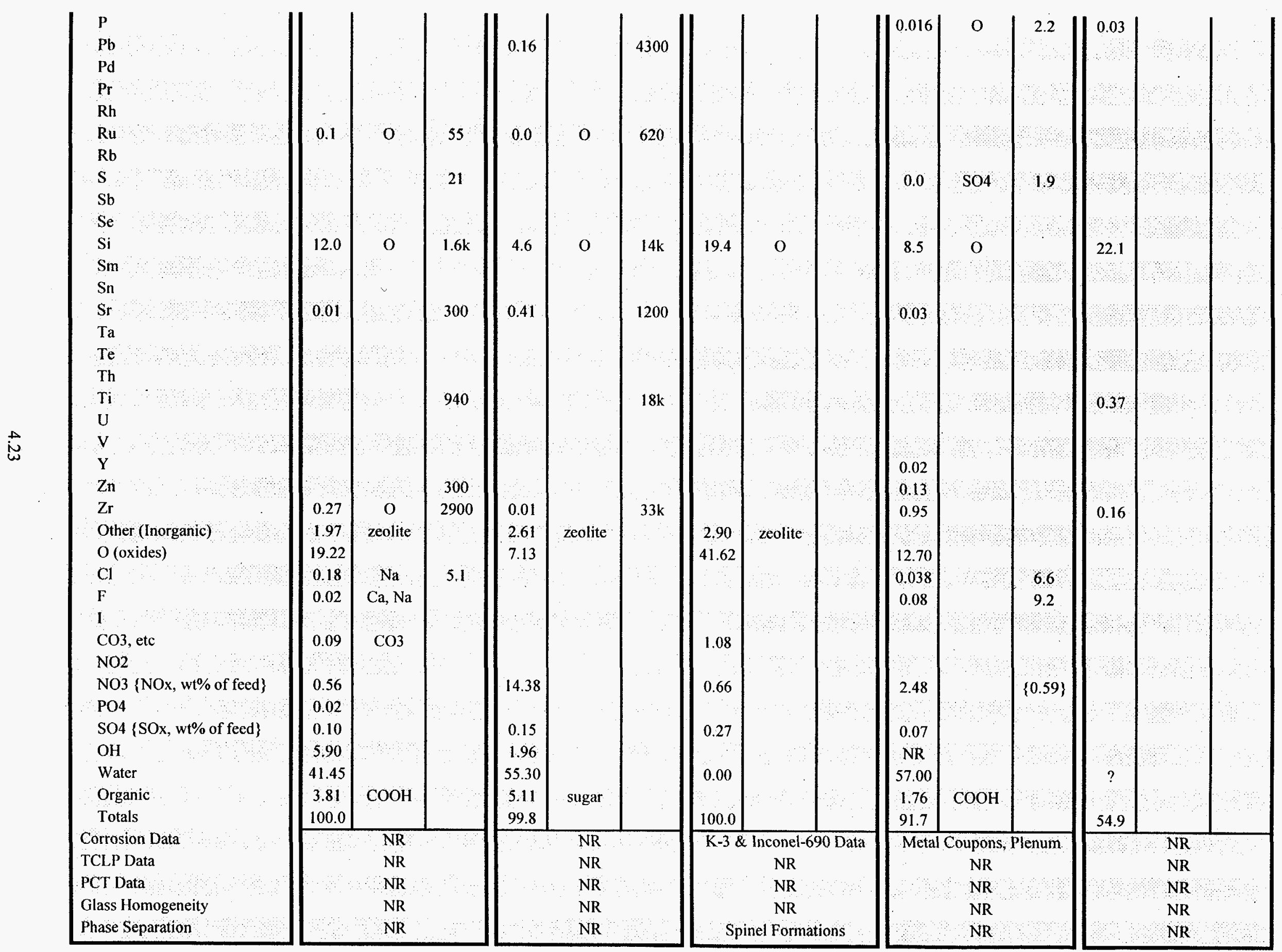




\begin{tabular}{|l|}
\hline Company \\
Melter \\
Test Name \\
Feed Description \\
Reference(s) \\
Energy Source \\
Power $(\mathrm{kW} \cdot \mathrm{hr} / \mathrm{kg}$ glass) \\
Glass Temp. $\left.{ }^{\circ} \mathrm{C}\right)$ \\
Feed On' Time \\
Glass Surface Area $(\mathrm{m} 2)$ \\
Feed Rate $(\mathrm{kg} / \mathrm{hr})$ \\
Glass Production Rate $(\mathrm{kg} / \mathrm{hr})$ \\
$\mathrm{Specific}$ Glass Prod $(\mathrm{kg} / \mathrm{hr} \cdot \mathrm{m} 2)$ \\
Off-gas Solids $(\% \mathrm{feed})$ \\
Feed Type \\
Feed Composition: \\
$\mathrm{Ag}$ \\
$\mathrm{Al}$ \\
$\mathrm{As}$ \\
$\mathrm{B}$ \\
$\mathrm{Ba}$ \\
$\mathrm{Bi}$ \\
$\mathrm{C}$ \\
$\mathrm{Ca}$ \\
$\mathrm{Cd}$ \\
$\mathrm{Ce}$ \\
$\mathrm{Cr}$ \\
$\mathrm{Cs}$ \\
$\mathrm{Cu}$ \\
$\mathrm{Fe}$ \\
$\mathrm{Ge}$ \\
$\mathrm{Hf}$ \\
$\mathrm{Hg}$ \\
$\mathrm{K}$ \\
$\mathrm{La}$ \\
$\mathrm{Li}$ \\
$\mathrm{Mg}$ \\
$\mathrm{Mn}$ \\
$\mathrm{Mo}$ \\
$\mathrm{Na}$ \\
$\mathrm{Nd}$ \\
$\mathrm{Ni}$ \\
\end{tabular}

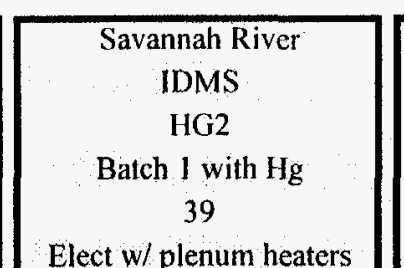

Elect w/ plenum heaters 12.7

$1050-1190$ NR

0.29

34.4 (estimate)

9.0

32.0

NR

slurry (assume $\mathrm{sg}=1.3$ )

\begin{tabular}{|c|c|c|}
\hline wt\% & Form & DF \\
\hline & & \\
\hline
\end{tabular}

\begin{tabular}{|l|l|l|}
\hline 2.58 & \\
\hline & &
\end{tabular}

1.85

0.08

0.82

0.08

0.07

0.12

9.15

$8 \mathrm{E}-4$

1.23

1.96

0.78

1.65

8.3

0.54

125.0

Savannah River
IDMS
HG3
Batch 1 with $\mathrm{Hg}$
39

Elect w/plenum heaters 8.1

$1050-1190$ NR

0.29

34.4 (estimate)

14.0

47.0

NR

slurry (assume $\mathrm{sg}=1.3$ )

\begin{tabular}{|c|c|c|}
\hline$w t \%$ & Form & DF \\
\hline 2.82 & & \\
\hline
\end{tabular}

2.2

2.23
0.08

0.89

0.16

9.99

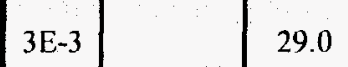

189

2.2

0.9

1.76

6.4

0.58

\begin{tabular}{|c|}
\hline Savannah River \\
IDMS \\
HWVP1 \\
NCAW 91 \\
44 \\
\hline
\end{tabular}

Elect w/ plenum heaters

NR

1125

NR

0.29

30.2

NR

NR

NR

slurry

\begin{tabular}{|c|c|c|}
\hline wt\% & Form & DF \\
\hline 0.04 & & {$[0.195]$} \\
1.45 & $\mathrm{OH}$ & \\
\hline
\end{tabular}

1

4.03

0.04

0

$\mathrm{OH}$

026

$0.26 \quad \mathrm{OH}$

$0.9 \quad \mathrm{OH}$

$0.22 \mathrm{OH}$

0.08

0.16

$0.06 \quad \mathrm{SO} 4$

$4.97 \mathrm{OH}$

29.0

0.15

0.2

2.23

0.09

$0.13 \quad 0$

5.9

1.97

0.46

$\mathrm{O}$

\begin{tabular}{|c|}
\hline Savannah River \\
IDMS \\
HWVP2 \\
NCAW 91 \\
44 \\
Elect w/ plenum heaters
\end{tabular}

Elect w/ plenum heaters

NR

1125

NR

0.29

35.2

11.5

39.6

NR.

slurry

\begin{tabular}{|c|c|c|}
\hline $\mathrm{w} t \%$ & Form & $\mathrm{DF}$ \\
\hline 0.05 & & {$[0]$} \\
\hline
\end{tabular}

\begin{tabular}{|r|r|r}
1.42 & OH & \\
4.17 & 0 &
\end{tabular}

4.17

0.05

0.28

0.8

0.11

0.05

0.1

$0.07 \quad \mathrm{SO} 4$

531

5.31
0.02

$\int$

0.1

2.39

0 .

$0.11 \mathrm{OH}$

$0.43 \mathrm{OH}, \mathrm{O}$

$0.11 \quad \mathrm{O}$

6.1

0.93

0.47
0.93

$\mathrm{OH}$

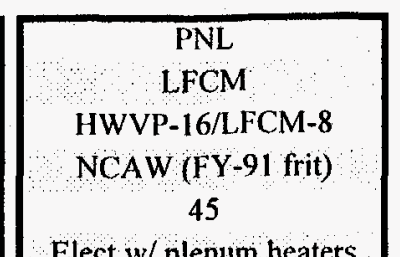

Elect w/ plenum heaters

5.5

1162

433 hours

1.05

74.0

250

23.8

0.03

slurry

\begin{tabular}{|c|c|c|}
\hline wt\% & Form & DF \\
\hline 0.006 & & 60 \\
0.51 & & 319 \\
\hline
\end{tabular}

1.25

0.018

0

647

694

250

626

317

128

541

739

2.00

0.41

0.1

$0.75 \quad 0$

0.054

0.18

0.041

160 ?

778

196

879

879
722 


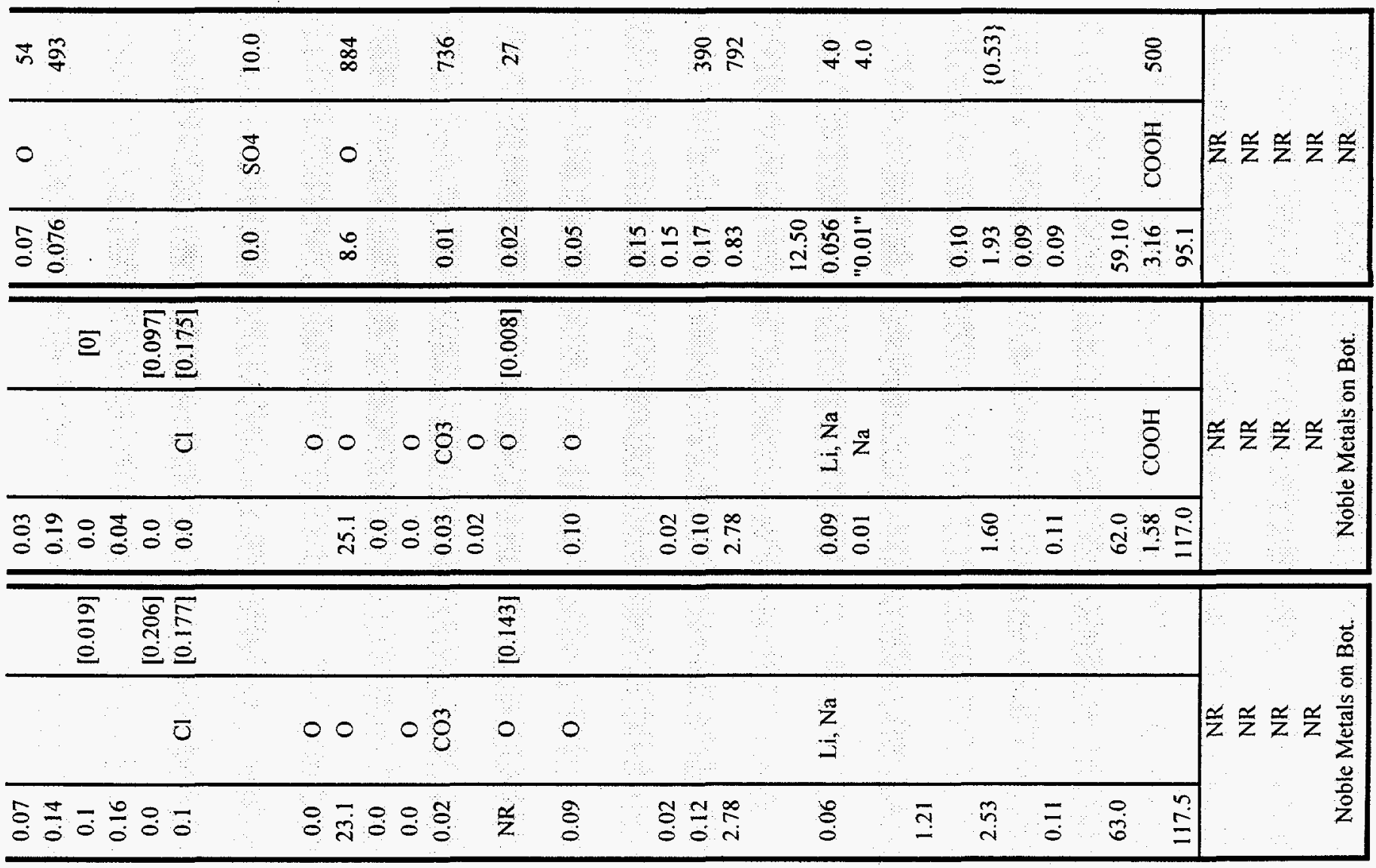

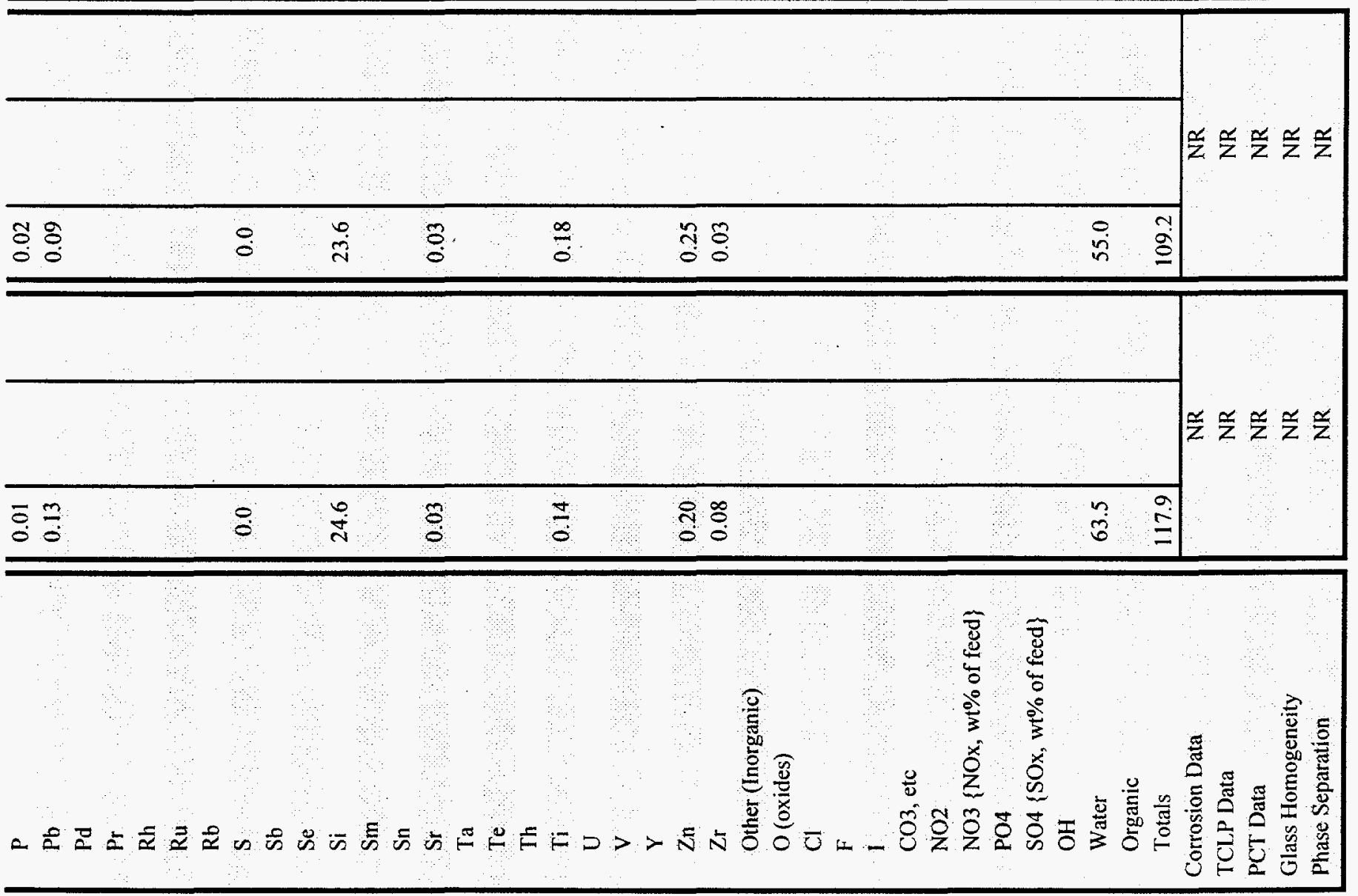




\begin{tabular}{|c|c|c|c|}
\hline $\begin{array}{l}\text { Company } \\
\text { Melter } \\
\text { Test Name } \\
\text { Feed Description } \\
\text { Reference(s) } \\
\text { Energy Source } \\
\text { Power (kW/hr/kg glass) } \\
\text { Glass Temp. }\left({ }^{\circ} \mathrm{C}\right) \\
\text { Feed 'On' Time } \\
\text { Glass Surface Area (m2) } \\
\text { Feed Rate }(\mathrm{kg} / \mathrm{hr}) \\
\text { Glass Production Rate }(\mathrm{kg} / \mathrm{hr}) \\
\text { Specific Glass Prod }(\mathrm{kg} / \mathrm{hr} \cdot \mathrm{m} 2) \\
\text { Off-gas Solids (\% feed) } \\
\text { Feed Type }\end{array}$ & Elect & $\begin{array}{r}\text { PNL } \\
\text { SSHTI } \\
\text { SSHTN } \\
\text { anford I } \\
47 \\
40 \text { plent } \\
3.5 \\
1350 \\
100 \text { ho } \\
0.21 \\
4 \text { (estim } \\
11.0 \\
52.0 \\
\text { NR } \\
\text { slurry }\end{array}$ & $\begin{array}{l}N \\
\text { heaters } \\
\end{array}$ \\
\hline Feed Composition: & $w t \%$ & Form & $\overline{\mathrm{DF}}$ \\
\hline $\mathrm{Ag}$ & & & 806 \\
\hline $\mathrm{Al}$ & 2.07 & $\mathrm{OH}$ & 4181 \\
\hline As & & & \\
\hline B & 0.61 & 0 & 243 \\
\hline $\mathrm{Ba}$ & & & 1035 \\
\hline $\mathrm{Bi}$ & & & \\
\hline C & & & \\
\hline $\mathrm{Ca}$ & 0.99 & $\mathrm{CO} 3$ & 6497 \\
\hline $\mathrm{Cd}$ & & & 29 \\
\hline $\mathrm{Ce}$ & 0.06 & & \\
\hline $\mathrm{Cr}$ & 0.02 & & 71 \\
\hline $\mathrm{Cs}$ & 0.06 & & \\
\hline $\mathrm{Cu}$ & 0.02 & & 760 \\
\hline $\mathrm{Fe}$ & 0.04 & & 148 \\
\hline $\mathrm{Ge}$ & & & \\
\hline Hf & & & \\
\hline $\mathrm{Hg}$ & & & \\
\hline $\mathrm{K}$ & 0.43 & $\mathrm{OH}$ & 42 \\
\hline La & 0.0 & & \\
\hline $\mathrm{Li}$ & & & 29 \\
\hline $\mathrm{Mg}$ & 0.05 & & 1369 \\
\hline $\mathrm{Mn}$ & & & 343 \\
\hline Mo & 0.04 & $\mathrm{Na}-\mathrm{O}$ & 49 \\
\hline $\mathrm{Na}$ & 5.3 & & 140 \\
\hline $\mathrm{Nd}$ & 0.07 & & 3739 \\
\hline $\mathrm{Ni}$ & & & 11285 \\
\hline
\end{tabular}




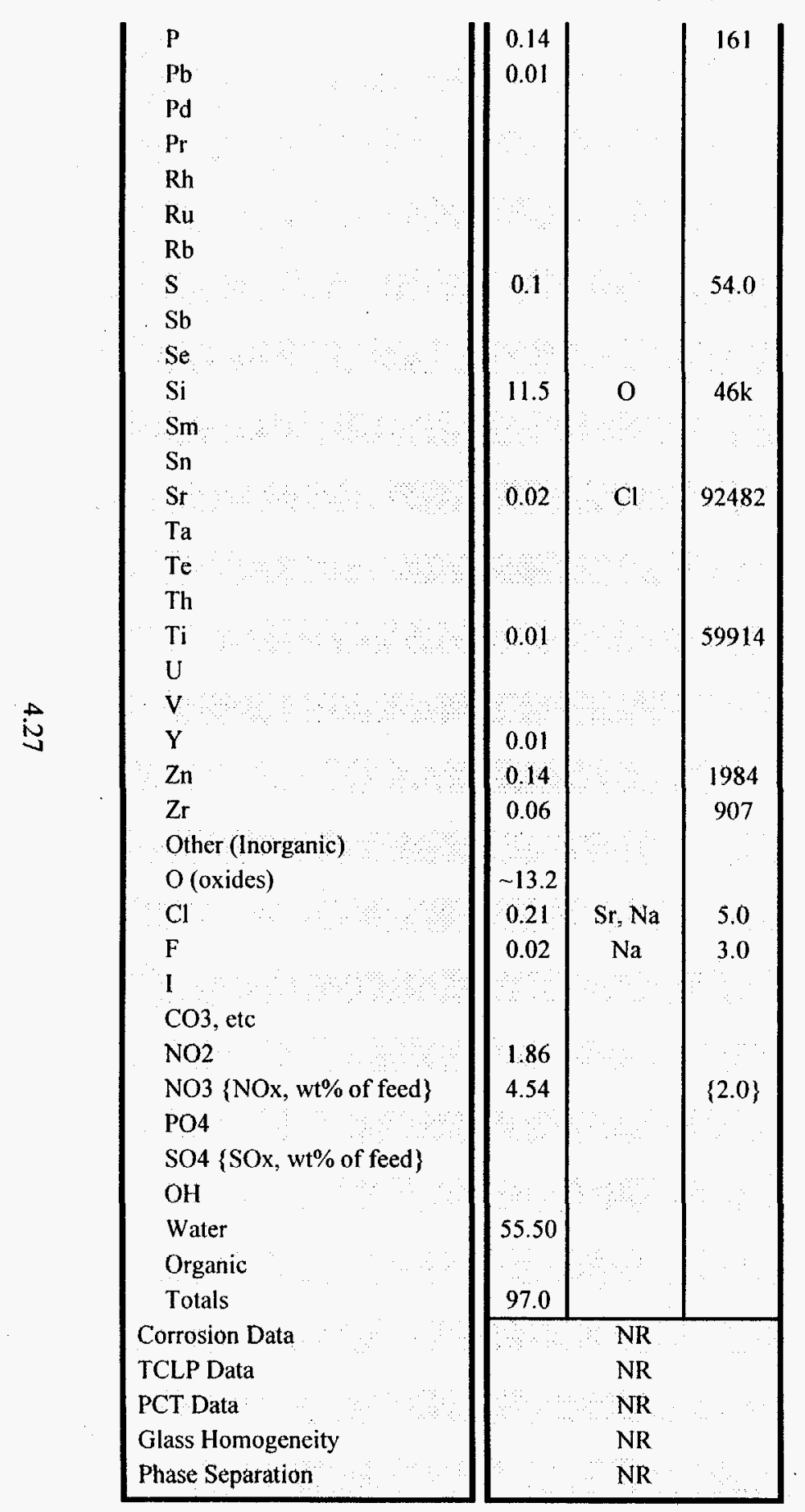


No. of

Copies

8 DOE Richland Field Office

N. R. Brown (6)

L. A. Huffman

G. H. Sanders

10 Westinghouse Hanford Company

K. C. Burgard

W. C. Eaton

R. L. Gibby

B. A. Higley

S. E. Kelly

F. J. Markowski

G. E. Stegen

G. F. Williamson

C. N. Wilson

J. A. Voogd

20 Pacific Northwest Laboratory

K.A. Blanchard

J. M. Creer

M. L. Elliott

C. J. Freeman (2)

P. R. Hrma

D. A. Lamar

D. E. Larson

J. M. Perez

G. J. Sevigny

J. H. Westsik

G. A. Whyatt

K. D. Wiemers

PNL/Information Release Office (7)

Distr. 1 